Research paper

\title{
Constraining foraminiferal calcification depths in the western Pacific warm pool
}

\author{
Nadine Rippert ${ }^{\mathrm{a}, *}$, Dirk Nürnberg ${ }^{\mathrm{b}}$, Jacek Raddatz ${ }^{\mathrm{b}, \mathrm{c}}$, Edith Maier ${ }^{\mathrm{a}}$, Ed Hathorne ${ }^{\mathrm{b}}$, \\ Jelle Bijma ${ }^{a}$, Ralf Tiedemann ${ }^{a}$ \\ a Alfred-Wegener-Institut Helmholtz Zentrum für Polar- und Meeresforschung, Postfach 1201 61, 27515 Bremerhaven, Germany

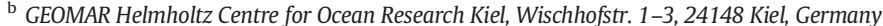 \\ c Goethe University Frankfurt, Institute of Geosciences, Altenhöferallee 1, 60438 Frankfurt am Main, Germany
}

\section{A R T I C L E I N F O}

\section{Article history:}

Received 9 February 2016

Received in revised form 5 August 2016

Accepted 31 August 2016

Available online 03 September 2016

\section{Keywords:}

Living planktonic foraminifera

Apparent calcification depth

Western equatorial Pacific

Stable oxygen and carbon isotopes

$\mathrm{Mg} / \mathrm{Ca}$ analyses

Foraminiferal vital effects

\begin{abstract}
A B S T R A C T
Insight into past changes of upper ocean stratification, circulation, and nutrient signatures rely on our knowledge of the apparent calcification depth (ACD) and ecology of planktonic foraminifera, which serve as archives for paleoceanographic relevant geochemical signals. The ACD of different species varies strongly between ocean basins, but also regionally. We constrained foraminiferal ACDs in the Western Pacific Warm Pool (Manihiki Plateau) by comparing stable oxygen and carbon isotopes $\left(\delta^{18} \mathrm{O}_{\text {calite, }}, \delta^{13} \mathrm{C}_{\text {calcite }}\right)$ as well as $\mathrm{Mg} / \mathrm{Ca}$ ratios from living planktonic foraminifera to in-situ physical and chemical water mass properties (temperature, salinity, $\delta^{18} \mathrm{O}_{\text {seawater }}$, $\delta^{13} C_{\mathrm{DIC}}$ ). Our analyses point to Globigerinoides ruber as the shallowest dweller, followed by Globigerinoides sacculifer, Neogloboquadrina dutertrei, Pulleniatina obliquiloculata and Globorotaloides hexagonus inhabiting increasing greater depths. These findings are consistent with other ocean basins; however, absolute ACDs differ from other studies. The uppermost mixed-layer species G. ruber and G. sacculifer denote mean calcification depths of $\sim 95 \mathrm{~m}$ and $\sim 120 \mathrm{~m}$, respectively. These Western Pacific ACDs are much deeper than in most other studies and most likely relate to the thick surface mixed layer and the deep chlorophyll maximum in this region. Our results indicate that $N$. dutertrei appears to be influenced by mixing waters from the Pacific equatorial divergence, while P. obliquiloculata with an ACD of $\sim 160 \mathrm{~m}$ is more suitable for thermocline reconstructions. ACDs of G. hexagonus reveal a deep calcification depth of $\sim 450 \mathrm{~m}$ in oxygen-depleted, but nutrient-rich water masses, consistent to other studies. As the $\delta^{13} \mathrm{C}$ of $\mathrm{G}$. hexagonus is in near-equilibrium with ambient seawater, we suggest this species is suitable for tracing nutrient conditions in equatorial water masses originating in extra-topical regions.
\end{abstract}

(c) 2016 Elsevier B.V. All rights reserved.

\section{Introduction}

Geochemical signals of planktonic foraminifera shells (=tests) are frequently used for paleoceanographic studies as they well reflect past environmental conditions (e.g., Shackleton, 1974; Ravelo and Fairbanks, 1992; Nürnberg, 1995; Nürnberg et al., 1996; Bemis et al., 1998; Elderfield and Ganssen, 2000; Lea et al., 2000). Many species, however, are known to migrate through the water column during their life cycle and thus, their geochemical signals most likely provide an integrated signal across both the entire water depth range and the entire ontogenetic (calcification) cycle of the species (e.g., Hemleben and Bijma, 1994). Hence, the foraminiferal habitat depths determined by these geochemical signals are best described by the term Apparent Calcification Depth (ACD). It should be noted that the shell weight and therefore the chemical signature of the shell as a whole is mainly determined by the chemical composition of the last few chambers.

\footnotetext{
* Corresponding author.

E-mail address: Nadine.Rippert@awi.de (N. Rippert).
}

Approaches using planktonic foraminifers as biotic carriers of geochemical signals generally emphasize the importance of the knowledge of foraminiferal ACDs. Since the first plankton tow studies of Bé (1959, 1962), efforts were launched to most reliably define the foraminiferal depth habitat (Thunell and Honjo, 1981; Fairbanks et al., 1982; Thunell et al., 1983). With the development of geochemical analysis on foraminiferal tests, it was further possible to assess foraminiferal ACD (Emiliani, 1955; Shackleton, 1974; Nürnberg, 1995; Faul et al., 2000; King and Howard, 2005; Regenberg et al., 2009; Steph et al., 2009; Wilke et al., 2009; Birch et al., 2013; Wejnert et al., 2013) These studies reveal significant regional intraspecific differences in the ACD (Faul et al., 2000; Steph et al., 2009). The species Globigerinoides ruber, for example, is often referred to as a "surface dweller", i.e. living within the upper $30 \mathrm{~m}$ of the water column (Hemleben et al., 1989; Faul et al., 2000; Steph et al., 2009; Birch et al., 2013). However, in cases of high sea surface temperatures (SST) and a deep chlorophyll maximum (DCM), it has been shown to descend to and calcify in deeper waters (Fairbanks et al., 1982; Wejnert et al., 2013). Contrary, the ACDs of Neogloboquadrina dutertrei scatter within the 40-200 m water depth range (Hemleben et 
al., 1989; Dekens et al., 2002; Steph et al., 2009; Faul et al., 2000; Nürnberg et al., 2015). Particularly, during strong upwelling the ACD can shoal from within the thermocline to distinctly shallower waters (Loubere, 2001). As the studies are scattered over the world oceans, reliable estimations of the ACDs of planktonic foraminifera in a specific area remains a challenge, which is further hampered by logistical difficulties.

The Western Pacific Warm Pool (WPWP) is the largest warm water area on Earth with SSTs consistently higher than $28^{\circ} \mathrm{C}$ (Fig. 1a) (Yan et al., 1992). The WPWP deep thermocline ( 175-300 $\mathrm{m}$ in the center of the WPWP; Andreasen and Ravelo, 1997) allows for a large heat capacity, making it the major source of heat and moisture transfer from low to high latitudes. In contrast, in the eastern equatorial Pacific (EEP) the thermocline reaches depths as shallow as $30 \mathrm{~m}$ (Locarnini et al., 2013). This asymmetric behaviour is also clearly seen in the zonal nitrate section (Fig. 1b), which points towards overall oligotrophic conditions in the WPWP and contrasting with fertile conditions in the EEP. Fluctuations in size and temperature of the WPWP are important drivers for the El Niño-Southern Oscillation (ENSO), the Asian monsoon system and, through atmospheric teleconnections, the global climate system (Sagawa et al., 2012). Despite the importance of the WPWP in the climate system, only little information about foraminiferal ACDs are available. To-date, the limited number of studies from the WPWP have concentrated on reconstructing upper ocean conditions with known ACDs from different regions (e.g., Wara et al., 2005; Russon et al., 2010) or focused on foraminiferal assemblages from the center of the WPWP near New Guinea (Kawahata et al., 2002; Yamasaki et al., 2008), or on plankton tows and surface sediments from the central equatorial Pacific (Watkins et al., 1996; Lynch-Stieglitz et al., 2015).
Our multinet study from the Manihiki Plateau attempts for the first time to define the modern ACDs of selected planktonic foraminifera at the south-eastern margin of the WPWP. Five modern planktonic foraminiferal species are studied: G. ruber (white), Globigerinoides sacculifer, N. dutertrei, Pulleniatina obliquiloculata and Globorotaloides hexagonus. We measured stable oxygen and carbon isotopes $\left(\delta^{18} \mathrm{O}_{\text {calcite, }}, \delta^{13} \mathrm{C}_{\text {calcite }}\right)$ as well as $\mathrm{Mg} / \mathrm{Ca}$ ratios on the foraminiferal calcite and compared these data to in-situ physical and chemical seawater characteristics

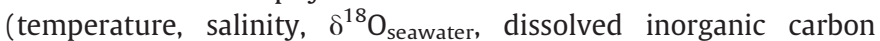
$\delta^{13} \mathrm{C}_{\text {DIC }}$ ). By doing so, we were able to better constrain species-specific ACD in an area with the thickest and warmest mixed layer on Earth and to determine the species-specific carbon-isotope disequilibrium. By doing so, we developed a great understanding of regional foraminiferal ACDs in the WPWP. We were then able to define to what extent the geochemical measurements deviate from predictions based on empirical relationships. Our study can be used to inform on what species to use for upper ocean water mass reconstructions of WPWP internal dynamics.

\subsection{Foraminiferal ecological preferences and hydrographic setting}

The abundance of planktonic foraminiferal species is strongly affected by environmental parameters such as, the thermal structure of the water column, salinity, and food supply (e.g., Bijma et al., 1990; Watkins et al., 1996; King and Howard, 2003; Žarić et al., 2005). Culture experiments and surface-sediment samples indicate temperature as one of the major environmental parameters affecting the foraminiferal biogeographic distribution (Bé and Tolderlund, 1971; Bijma et al., 1990; Morey et al., 2005). Even though most planktonic foraminifera
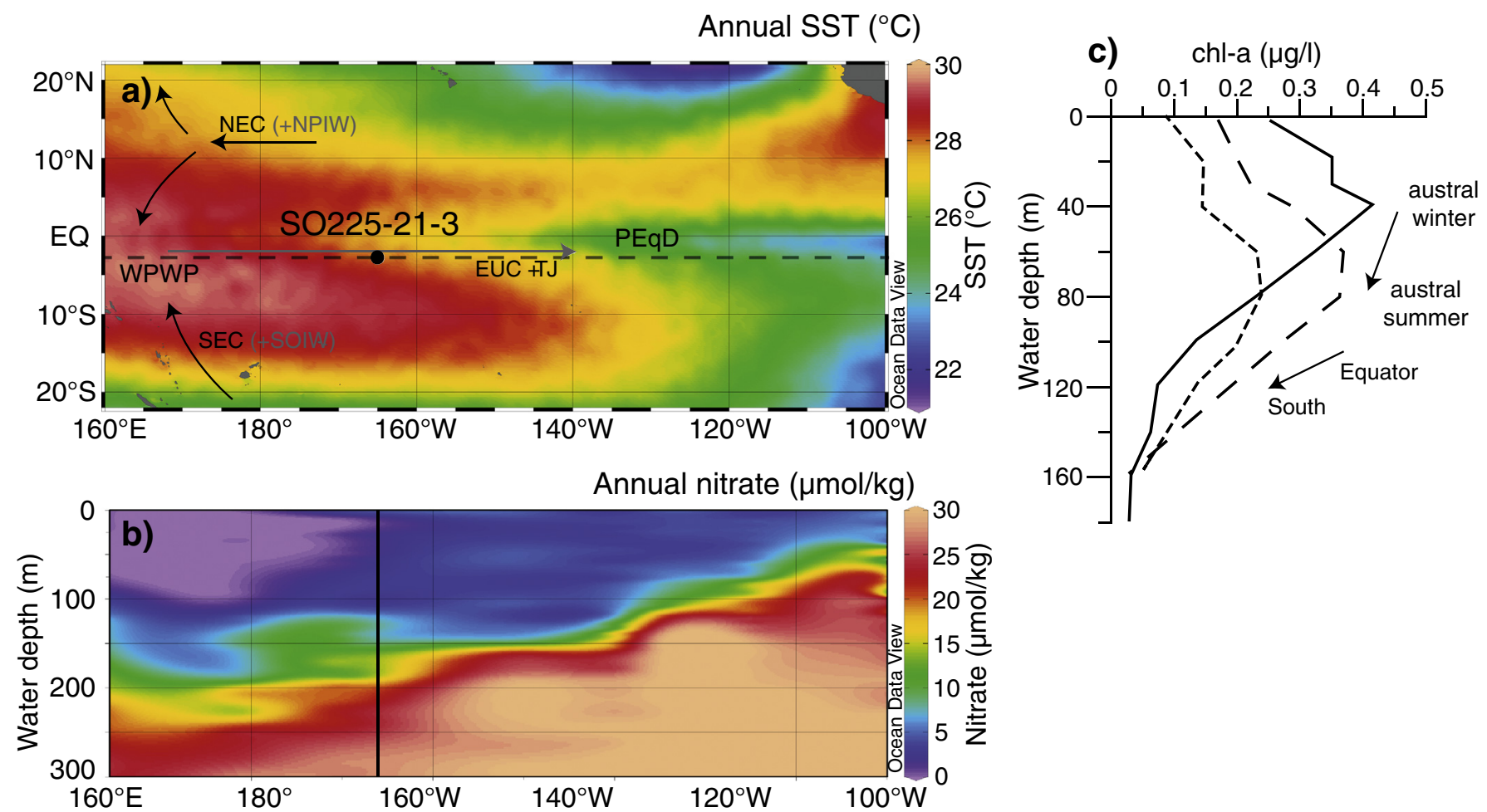

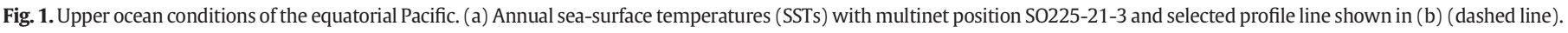

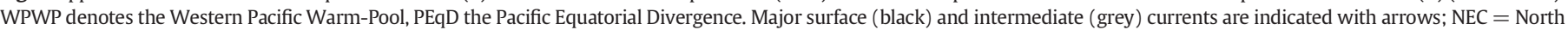

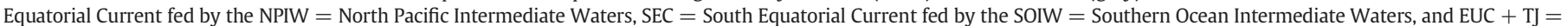

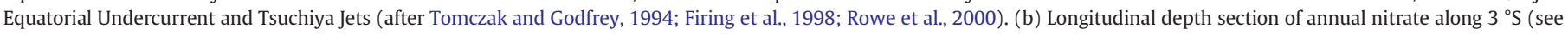

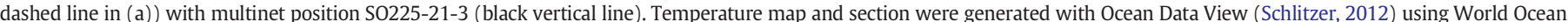

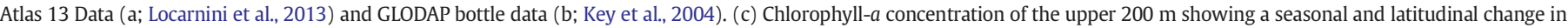

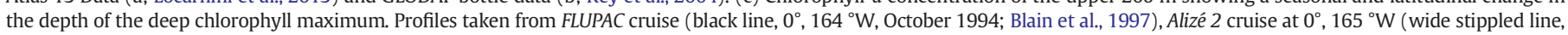
February 1991; Reverdin et al., 1991) and Alizé 2 cruise at $2.5^{\circ} \mathrm{S}, 168^{\circ} \mathrm{W}$ (narrow stippled line, February 1991; Reverdin et al., 1991 ), respectively. 
have a large temperature tolerance of about $14-32{ }^{\circ} \mathrm{C}$ (Bijma et al., 1990; Mulitza et al., 1998), they all have an individual, far more restricted optimum temperature (e.g., $23.5^{\circ} \mathrm{C}$ for G. sacculifer) at which chamber formation, gametogenesis, and food acceptance is highest (Bijma et al., 1990). In contrast, the salinity tolerance range in planktonic species is wider than variations encountered in the open oceans (e.g., 24-47 in G. sacculifer; Bijma et al., 1990), thus, salinity plays most likely a marginal role for the foraminiferal distribution. Salinity, however, can influence the vertical distribution of planktonic foraminifera indirectly by changing the density structure of the water column and thereby restricting vertical movement and the accumulation of nutrients in certain depths (Bijma et al., 1990).

The WPWP at the Manihiki Plateau is characterized by high annual SSTs and sea-surface salinities (SSS) of $28 \pm 0.2{ }^{\circ} \mathrm{C}$ and $35 \pm 0.03$ (psu), respectively (Locarnini et al., 2013; Zweng et al., 2013). Sediment trap results from the WPWP reveal that despite the small seasonal SST range of $\pm 0.2{ }^{\circ} \mathrm{C}$, planktonic foraminifera are not present all year round in high abundances (Kawahata et al., 2002; Lin et al., 2004). The production is rather controlled by local nutrient availability and light intensity (Kawahata et al., 2002). As a consequence of the oligotrophic surface waters in the WPWP, with nutrient concentrations of $<0.1 \mathrm{mM} \mathrm{NO}_{3}^{-}$and $<0.2 \mathrm{mM} \mathrm{PO}_{4}$ (Blanchot et al., 2001; Le Borgne et al., 2002; Rafter and Sigman, 2015), primary production is low and foraminiferal fluxes are modest (mean 171 shells $\mathrm{m}^{-2}$ day $^{-1}$; Kawahata et al., 2002). In contrast, the high-nutrient low-chlorophyll (HNLC) region of the Pacific Equatorial Divergence is enriched in macronutrients ( $>3 \mathrm{mM} \mathrm{NO}_{3}^{-} ;>0.4 \mathrm{mM} \mathrm{PO}_{4}$ ) and foraminiferal fluxes are higher (up to 430 shells $\mathrm{m}^{-2}$ day $^{-1}$; Thunell and Honjo, 1981). Through a complex and highly dynamic current system (e.g., Wyrtki and Kilonski, 1984; Fine et al., 1994; Tomczak and Godfrey, 1994; Johnson and Moore, 1997; Rowe et al., 2000; Goodman et al., 2005; Grenier et al., 2011), including the South Equatorial Current (SEC), the persistent eastward-directed subsurface Equatorial Undercurrent (EUC) and the Tsuchiya Jets (after Tsuchiya, 1972), nutrients are transported via intermediate and mode waters from the extratropical HNLC regions to the thermocline of the Western Equatorial Pacific and upwell along the equator in the Pacific equatorial divergence.

In the vicinity of the nutricline, chlorophyll-a concentrations reach a maximum between 40 and 90 m water depths in the WPWP indicating the DCM (Fig. 1c). Planktonic foraminifera respond to the distribution of chlorophyll and high abundances are often associated with the DCM (Fairbanks et al., 1982; Schiebel et al., 2001). Even though the depth of the DCM does not change significantly from east to west (Le Borgne et al., 2002), it changes meridionally. Upwelling decreases away from the equator and, as a consequence, the DCM deepens. The DCM depth also varies seasonally: while the DCM at the equator is situated at $\sim 60 \mathrm{~m}$ (range $\sim 40-80 \mathrm{~m}$, values $>0.3 \mathrm{mg} \mathrm{m}^{-3}$ ) during austral summer, it shoals during autumn and reaches its shallowest position during austral winter (25-70 m, maximum $40 \mathrm{~m}$ ) (Le Borgne et al., 2002).

Variations in upper ocean temperatures, depth of the thermocline and hence, nutrients in the upper water column, are influenced by the ENSO climate phenomenon (Collins et al., 2010). Nevertheless, the Oceanic Niño Index (ONI), a standard for identifying El Niño and La Niña events through averaging SST anomalies, was only slightly increased $\left(0.2-0.4^{\circ} \mathrm{C}\right.$ ) from August to December 2012 (NOAA, 2015a), thus indicating only a tendency for a very weak El Niño $\left(\mathrm{ONI}>0.5^{\circ} \mathrm{C}\right)$.

\section{Material and methods}

\subsection{Sample material}

During the RV SONNE cruise SO225, in-situ temperature, salinity and oxygen measurements were conducted with a conductivity-temperature-depth (CTD) device equipped with a 24 in each case 101 bottle-rosette system (SO225-21- $13.05^{\circ} \mathrm{S},-165.056^{\circ} \mathrm{W}$; Werner et al., 2013). The water column was sampled at 15 depths, and for each water depth a
$50 \mathrm{ml}$ and a $100 \mathrm{ml}$ subsamples was taken and stored in glass bottles for $\delta^{13} \mathrm{C}$ and $\delta^{18} \mathrm{O}_{\text {seawater }}$ measurements, respectively. Water samples for carbon isotope analysis were poisoned with $100 \mu$ of saturated $\mathrm{HgCl}_{2}$ solution to prevent biological activity and sealed with beeswax to prevent interaction with air.

At the same location where SO225-21-1 was recovered, a multiple open/closing plankton net was run during the night at the northernmost edge of the Manihiki Plateau in the WPWP (SO225-21-3; Werner et al., 2013) (Fig. 1a). The multinet (HydroBios, Kiel) with a square mouth opening of $50 \times 50 \mathrm{~cm}, 55 \mu \mathrm{m}$ mesh size, and five net bags allowed stratified vertical sampling in five depth intervals within the first $500 \mathrm{~m}$ of the water column. The depths were selected after viewing the CTD cast and thus, included the sea surface $(0-50 \mathrm{~m})$, sub-surface (50-100 m), upper thermocline (100-200 m), lower thermocline (200-300 m) and sub-thermocline (300-500 m). These depth intervals are often investigated in paleoceanographic research (e.g., Spero et al., 2003; Wara et al., 2005; Kiefer et al., 2006; Pena et al., 2008; Regenberg et al., 2009; Nürnberg et al., 2015), highlighting the need to better understand the ACD of the species calcifying in these depths. Since the area is known for low primary production, we selected relatively large net depth intervals to capture enough material for our analyses. Immediately after collection, plankton tow samples were preserved with an Ethanol-Bengal Rose solution.

\subsection{Handling foraminiferal assemblage counts}

In the laboratory, plankton net samples were sieved over $1000 \mu \mathrm{m}$ and $63 \mu \mathrm{m}$. Material $>1000 \mu \mathrm{m}$ was analysed for spinose species attached to particulate organic matter. Within the fraction $63-1000 \mu \mathrm{m}$ intact planktonic foraminifera $>125 \mu \mathrm{m}$ were wet picked using a binocular microscope and dried afterward. As all individuals contained coloured cytoplasm in the early chambers, we infer that the samples were collected alive or shortly after they died. Smaller-sized planktonic foraminifera are more difficult to define taxonomically. As we primarily focus on size fractions well established for paleoceanographic purposes ( $>250 \mu \mathrm{m})$, only foraminifera $>125 \mu \mathrm{m}$ were counted. Depending on the amount of material, samples were either quantitatively split into aliquots and approximately 200-400 foraminifera were identified or the whole sample was counted (Supplement Table S1). Further, we calculated the density of different species over the netted depth range using the formula: \#/(a*a)*b; with \# being the number of counted specimen, $a$ being the multinet-opening in meters and $b$ the depth interval the respective net was hauled.

Planktonic foraminiferal taxonomy follows the work of Parker (1962), Bé (1977) and Hemleben et al. (1989). We are aware that G. ruber (white) exists in different morphotypes. The determination of the morphotypes sensu strictu (s.s.) and sensu lato (s.l.) follows the concept of Wang (2000), in which G. ruber s.s. has spherical chambers sitting symmetrically over previous sutures with high arched apertus and $G$ ruber s.l. corresponds to more compressed subspherical chambers with a small aperture. These different morphotypes have been shown to dwell at slightly different water depths, yet always at the sea surface (e.g., Wang, 2000; Steinke et al., 2005; Kuroyanagi et al., 2008). For our analyses we selected mainly the morphotype s.s., but due to limited amount of material, we also included some specimen of the slightly deeper-dwelling morphotype s.l. for the isotope analyses when necessary.

\subsection{Determination of $\mathrm{Mg} / \mathrm{Ca}$ ratios and calculation of water temperatures}

$\mathrm{Mg} / \mathrm{Ca}$ ratios of planktonic foraminiferal calcite were measured to assess the water temperature during test growth. Prior to the analysis, the cytoplasm within the test was removed by treating the foraminiferal shells with $7 \%$ sodium hypochlorite $(\mathrm{NaClO})$ before rinsing with deionised water. Intact specimens were selected from the 320-760 $\mu \mathrm{m}$ 
size fraction as a narrower size range was prevented by the rather low amount of material (Table 1 ).

The geochemical analyses were obtained with the Excimer ArF $193 \mathrm{~nm}$ laser ablation system from NEW Wave ESI with a two-volume ablation cell design, coupled to an Agilent 7500cs Inductively Coupled Plasma-Mass Spectrometer (LA-ICP-MS) at GEOMAR. This micro-analytical technique enables the measurement of element/Ca through the shell wall of individual chambers. However, for the habitat assessment we use the mean $\mathrm{Mg} / \mathrm{Ca}$ ratios of all the chambers in the final whorl of each shell that could be targeted with the laser. Hemleben and Bijma (1994) demonstrated that the vast majority of the shell mass and therefore most of the geochemical signal is contained in the last few chambers. Measuring as many chambers as possible is important as $\mathrm{Mg} / \mathrm{Ca}$ seems to vary randomly from chamber to chamber in cultures under constant environmental conditions (de Nooijer et al., 2014). Thus, we analysed as many chambers as possible to ensure that we have sampled as much of the shell as possible. Culturing studies have investigated the difference between whole-test calibrations and $\mathrm{Mg} / \mathrm{Ca}$-temperature equations based on $\mathrm{Mg} / \mathrm{Ca}$ measurements of the last chambers and found no significant difference between them (Kunioka et al., 2006; Dueñas-Bohórquez et al., 2009, 2011; Spero et al., 2015). The laser was targeted on the test surface, ablating through the test wall with a $50 \mu \mathrm{m}$ diameter spot size, and stopped when the wall was penetrated. Ablations were conducted in a He atmosphere and the laser energy density was between 0.97 and $1.85 \mathrm{~J} / \mathrm{cm}^{2}$ with a laser repetition rate of $5 \mathrm{~Hz}$. The ablation was done on as many chambers as possible (f to $f-4$ ), always proceeding from the outside of the test towards the inside. Time-resolved signals of ${ }^{24} \mathrm{Mg}$ were selected for integration and the mean background intensities (gas blank) were subtracted. Signal intensities were internally standardised to ${ }^{43} \mathrm{Ca}$ to account for variations in ablation yield. $\mathrm{Mg} / \mathrm{Ca}$ intensity ratios were calibrated with analyses of the international reference NIST 610 and NIST 612 glasses after every 10 sample spots (using values from Jochum et al., 2011), which were ablated with a higher energy density (around $2.65 \mathrm{~J} / \mathrm{cm}^{2}$ ). A powder pellet of the powdered reference material JCp-1 (Porites sp.) was ablated like a sample and the repeated measurements during the analytical session $(n=6)$ gave a relative standard deviation of $7.4 \%(1 \sigma)$ for $\mathrm{Mg} / \mathrm{Ca}$ with an average value of $\sim 3.707 \mathrm{mmol} / \mathrm{mol}$ that is $11 \%$ less than the solution ICP-MS consensus value from Hathorne et al. (2013) (4.199 mmol/mol).

Core top and culture studies point towards a species-specific dependency of the Mg incorporation into foraminiferal tests due to the interplay of biological processes and ecological behaviour (e.g., Nürnberg et al., 1996; Lea et al., 1999; Regenberg et al., 2009; Nehrke et al., 2013; Mewes et al., 2015). As a consequence, various species-specific calibrations have been established that have all basic similarities, but produce significantly different temperature estimates when applied to the same $\mathrm{Mg} / \mathrm{Ca}$ ratios. Hence, the accurate selection of the applied calibration curve is crucial. To find the most reliable calibration curve for each investigated foraminiferal species from the multinet samples, we converted the measured whole-shell foraminiferal $\mathrm{Mg} / \mathrm{Ca}$ ratios (Supplement Table S2) into temperatures using generic and species-specific equations if available (Supplement S3, Supplement Table S3). At the depth

Table 1

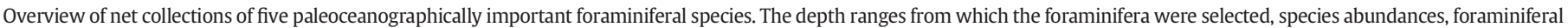
shell sizes, number of tests measured as well as geochemical analyses are given.

\begin{tabular}{|c|c|c|c|c|c|c|c|}
\hline \multirow[b]{2}{*}{ Species } & \multirow[b]{2}{*}{ Net depth (m) } & \multirow[b]{2}{*}{$\# / \mathrm{m}^{3}$} & \multirow[b]{2}{*}{ Shell size (range in $\mu \mathrm{m}$ ) } & \multirow[b]{2}{*}{ Number of tests measured } & \multicolumn{3}{|c|}{ Accomplished measurement } \\
\hline & & & & & $\delta^{18} \mathrm{O}_{\text {calcite }}(\%)$ & $\delta^{13} C_{\text {calcite }}(\%)$ & Mean $\mathrm{Mg} / \mathrm{Ca}(\mathrm{mmol} / \mathrm{mol})$ \\
\hline \multirow[t]{7}{*}{ G. ruber } & $0-50$ & 5.60 & $150-250$ & 18 & $-2.25 \pm 0.012$ & $-0.04 \pm 0.009$ & \\
\hline & $0-50$ & 5.60 & $250-300$ & 11 & $-2.17 \pm 0.01$ & $0.71 \pm 0.008$ & \\
\hline & $50-100$ & 6.00 & $150-250$ & 17 & $-2.68 \pm 0.02$ & $0.02 \pm 0.006$ & \\
\hline & $50-100$ & 6.00 & $250-300$ & 14 & $-2.40 \pm 0.004$ & $0.46 \pm 0.007$ & \\
\hline & $50-100$ & 6.00 & $300-350$ & 9 & $-2.47 \pm 0.05$ & $0.79 \pm 0.025$ & \\
\hline & $100-200$ & 0.84 & $\sim 410$ & 1 & & & $4.71 \pm 0.4$ \\
\hline & $300-500$ & 0.12 & $\sim 320$ & 1 & & & $5.10 \pm 0.8$ \\
\hline \multirow[t]{14}{*}{ G. sacculifer } & $0-50$ & 11.04 & $300-350$ & 7 & $-2.30 \pm 0.008$ & $1.18 \pm 0.008$ & \\
\hline & $0-50$ & 11.04 & $350-500$ & 4 & $-2.31 \pm 0.007$ & $1.31 \pm 0.004$ & \\
\hline & $0-50$ & 11.04 & $\sim 520$ & 1 & & & $4.27 \pm 0.6$ \\
\hline & $0-50$ & 11.04 & $\sim 520$ & 1 & & & $4.50 \pm 0.4$ \\
\hline & $50-100$ & 9.84 & $300-350$ & 5 & $-2.33 \pm 0.05$ & $0.83 \pm 0.025$ & \\
\hline & $50-100$ & 9.84 & $350-500$ & 4 & $-2.32 \pm 0.006$ & $1.00 \pm 0.006$ & \\
\hline & $50-100$ & 9.84 & $350-500$ & 4 & $-1.89 \pm 0.01$ & $1.34 \pm 0.008$ & \\
\hline & $50-100$ & 9.84 & $>500$ & 2 & $-2.27 \pm 0.01$ & $1.53 \pm 0.007$ & \\
\hline & $100-200$ & 6.64 & $300-350$ & 6 & $-2.39 \pm 0.01$ & $0.56 \pm 0.007$ & \\
\hline & $100-200$ & 6.64 & $350-500$ & 5 & $-2.43 \pm 0.01$ & $1.02 \pm 0.009$ & \\
\hline & $100-200$ & 6.64 & $350-500$ & 5 & $-1.94 \pm 0.01$ & $0.73 \pm 0.005$ & \\
\hline & $100-200$ & 6.64 & $>500$ & 3 & $-2.11 \pm 0.04$ & $0.99 \pm 0.018$ & \\
\hline & $200-300$ & 0.40 & $>500$ & 2 & $-2.15 \pm 0.02$ & $1.29 \pm 0.023$ & \\
\hline & $300-500$ & 0.40 & $\sim 750$ & 1 & & & $4.88 \pm 0.2$ \\
\hline \multirow[t]{4}{*}{ N. dutertrei } & $50-100$ & 8.00 & $250-300$ & 12 & $-1.90 \pm 0.02$ & $-0.14 \pm 0.017$ & \\
\hline & $50-100$ & 8.00 & $300-350$ & 9 & $-2.15 \pm 0.02$ & $-0.08 \pm 0.008$ & \\
\hline & $50-100$ & 8.00 & $350-500$ & 6 & $-2.21 \pm 0.01$ & $0.03 \pm 0.006$ & \\
\hline & $100-200$ & 4.32 & $\sim 360$ & 1 & & & $3.21 \pm 0.2$ \\
\hline \multirow[t]{10}{*}{ P. obliquiloculata } & $50-100$ & 20.64 & $>500$ & 2 & $-1.75 \pm 0.04$ & $-0.01 \pm 0.028$ & \\
\hline & $50-100$ & 20.64 & $\sim 520$ & 1 & & & $3.16 \pm 0.05$ \\
\hline & $100-200$ & 20.48 & $350-500$ & 4 & $-1.62 \pm 0.01$ & $0.06 \pm 0.004$ & \\
\hline & $100-200$ & 20.48 & $350-500$ & 4 & $-1.83 \pm 0.01$ & $-0.01 \pm 0.003$ & \\
\hline & $100-200$ & 20.48 & $>500$ & 2 & $-1.54 \pm 0.004$ & $0.26 \pm 0.016$ & \\
\hline & $100-200$ & 20.48 & $>500$ & 2 & $-1.49 \pm 0.01$ & $0.25 \pm 0.012$ & \\
\hline & $100-200$ & 20.48 & $\sim 675$ & 1 & & & $3.11 \pm 0.1$ \\
\hline & $200-300$ & 0.52 & $>500$ & 2 & $-1.60 \pm 0.03$ & $0.11 \pm 0.008$ & \\
\hline & $200-300$ & 0.52 & $>500$ & 2 & $-1.42 \pm 0.01$ & $0.41 \pm 0.004$ & \\
\hline & $300-500$ & 0.20 & $\sim 640$ & 1 & & & $2.85 \pm 0.3$ \\
\hline \multirow[t]{4}{*}{ G. hexagonus } & $300-500$ & 1.76 & $250-300$ & 10 & $1.39 \pm 0.05$ & $-0.06 \pm 0.01$ & \\
\hline & $300-500$ & 1.76 & $300-350$ & 9 & $1.59 \pm 0.01$ & $0.22 \pm 0.003$ & \\
\hline & $300-500$ & 1.76 & $350-500$ & 6 & $1.49 \pm 0.005$ & $0.24 \pm 0.006$ & \\
\hline & $300-500$ & 1.76 & $\sim 400$ & 1 & & & $1.36 \pm 0.4$ \\
\hline
\end{tabular}


interval in which a species was found in highest abundance on the Manihiki Plateau (see Section 3.2), we determined the mean temperature during sampling time from both CTD data and the seasonal range in temperature from the WOA13 data (Locarnini et al., 2013) at the same location. By comparing the in-situ temperatures with the $\mathrm{Mg} / \mathrm{Ca}$-derived temperatures, we identified the most suitable calibration equation for each species at our study site (Table 2, Supplement S3).

\subsection{Stable isotope analyses}

Stable oxygen and carbon isotope ratios $\left(\delta^{18} \mathrm{O}_{\text {calcite }}\right.$ and $\left.\delta^{13} \mathrm{C}_{\text {calcite }}\right)$ of the foraminiferal tests (Table 1 ) were determined to estimate the ACD by comparing measured $\delta^{18} \mathrm{O}_{\text {calcite }}$ to predicted $\delta^{18} \mathrm{O}_{\text {calcite }}$ as well as to assess the deviation from prediction based on empirical relationships. The isotope ratios were measured on a ThermoScientific MAT 253 mass spectrometer coupled to an automatic carbonate preparation device Kiel CARBO IV at AWI. The isotope measurements were calibrated via the international standard NBS 19 to the VPDB scale. All results are given in the common $\delta$-notation versus VPDB. The precision of the measurements, determined over a one-year period and based on repeated analysis of an internal laboratory standard (Solnhofen limestone), is $\pm 0.06 \%$ and $\pm 0.08 \%$ o ( $1 \sigma)$ for carbon and oxygen isotopes, respectively.

Measurements of the oxygen isotope composition of seawater $(\delta$ ${ }^{18} \mathrm{O}_{\text {seawater }}$ ) were performed on a ThermoScientific Delta $\mathrm{S}$ mass spectrometer and those for the seawater dissolved inorganic carbon isotope composition $\left(\delta^{13} \mathrm{C}_{\mathrm{DIC}}\right)$ were made with a ThermoScientific MAT 252 coupled to a Gas Bench II at AWI. The $\delta^{18} \mathrm{O}_{\text {seawater }}$ values are given in $\delta$-notation versus VSMOW and $\delta^{13} C_{\text {DIC }}$ values versus VPDB. The precision determined over a one-year period is $\pm 0.03 \%$ o ( $1 \sigma)$ for $\delta$ ${ }^{18} \mathrm{O}_{\text {seawater }}$ and $\pm 0.1 \%$ 。 $(1 \sigma)$ for $\delta^{13} \mathrm{C}_{\text {DIC. }}$.

\subsection{Estimation of the apparent calcification depth}

We constrained the ACDs of selected planktonic foraminiferal species by combining two approaches. This enables us to assess the ACD with improved accuracy. First, we compared the measured foraminiferal $\delta^{18} \mathrm{O}_{\text {calcite }}$ to calculated $\delta^{18} \mathrm{O}_{\text {equilibrium values at different water depths }}$ and hence, different temperatures. The water depth from which $\delta$ ${ }^{18} \mathrm{O}_{\text {calcite }}$ matches $\delta^{18} \mathrm{O}_{\text {equilibrium }}$ is taken as the isotope-ACD (Table 3). The expected $\delta^{18} \mathrm{O}_{\text {equilibrium }}$ values were calculated using paleotemperature-equations of Shackleton (1974), Kim and O'Neil (1997), Bemis et al. (1998; Orbulina universa high light), and Mulitza et al. (2004) (Supplement Table S4). In them, we inserted our measured variables foraminiferal $\delta^{18} \mathrm{O}_{\text {calcite, }}$, seawater $\delta^{18} \mathrm{O}$ (converted into VPDB by subtracting $-0.27 \%$; Hut, 1987 ), and modern temperatures from CTD data. Different equations were tested to show that relative species order in the water column is independent of the $\delta^{18} \mathrm{O}$-paleotemperature equation. The absolute isotope-ACDs, however, differ with each equation (Supplement Table S4). In cases where $\delta^{18} \mathrm{O}_{\text {calcite }}$ values were

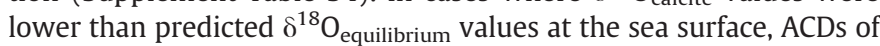
$5 \mathrm{~m}$ water depth were assigned (Supplement Table S4). ACDs derived by Shackleton (1974) and Kim and O'Neil (1997) are similar at the sea surface. In deeper waters, Shackletons' (1974) equation produces markedly shallower isotope-ACDs than Kim and O'Neils' (1997). On the other hand, the equations of Bemis et al. (1998) and Mulitza et al. (2004), that were both generated using planktonic foraminifera, yield deeper isotope-ACDs at all depths. Nevertheless, using Mulitza et al. (2004) for upper-ocean dwelling species (0-220 m), the number of samples with measured $\delta^{18} \mathrm{O}_{\text {calcite }}$ that are lower than the respective $\delta^{18} \mathrm{O}_{\text {equilibrium }}$ at the sea surface is minimised. In deeper waters, however, the equation of Mulitza et al. (2004) yield isotope-ACDs of up to $660 \mathrm{~m}$ (Supplement Table S4), and these are deeper than the nets were hauled. As a consequence, we selected the equation by Kim and O'Neil (1997), which was calibrated using inorganic calcite, for sub-thermocline waters (220-500 m, Table 2 ). Seasonal variations in $\delta^{18} \mathrm{O}_{\text {equilibrium }}$ due to varying temperature are considered by using temperature data from the WOA13 database to account for temperature variations during the foraminiferal life cycle (Table 3) (Locarnini et al., 2013). To assess the influence of species-specific offsets from $\delta^{18} \mathrm{O}_{\text {equilibrium, }}$, we corrected the measured $\delta^{18} \mathrm{O}_{\text {calcite }}$ values for disequilibrium effects (values are taken from Niebler et al., 1999 and Steph et al., 2009) and recalculated the $\delta^{18} \mathrm{O}$-derived ACDs with the Mulitza et al. (2004) and Kim and O'Neil (1997) equations (Supplement Table S4).

In a second step, we compared the temperatures converted from the average $\mathrm{Mg} / \mathrm{Ca}$ of living specimens (Table 1 ) to the ocean temperatures prevailing during the time of sampling (December 2012) at the sample location and placed the temperature-ACD at the according water depth (Table 3). To account for seasonal variations in the temperature record, we also compared the derived $\mathrm{Mg} / \mathrm{Ca}$ temperatures to austral winter and austral summer temperatures (data from WOA13) (Table 3) (Locarnini et al., 2013).

In a last step, we combined both $\mathrm{ACD}$ approaches and determined the mean $\mathrm{ACD}$. We are aware, that we have an uneven distribution between $\delta^{18} \mathrm{O}$ and $\mathrm{Mg} / \mathrm{Ca}$ measurements (Table 1 ). Thereby, more credit is given towards the $\delta^{18} \mathrm{O}$-derived ACD. To validate the combined mean ACD, we used the mean temperature and mean $\delta^{18} \mathrm{O}_{\text {calcite }}$ of the respective species and calculated the $\delta^{18} \mathrm{O}_{\text {water }}$. For this purpose we selected different paleotemperature equations (Supplement S5, Supplement Table S5) and rearranged the equations for the $\delta^{18} \mathrm{O}_{\text {water }}$. The $\delta^{18} \mathrm{O}_{\text {water }}$ was then compared to the measured $\delta^{18} \mathrm{O}_{\text {seawater }}$ (Supplement S5). It demonstrates that the calculated $\delta^{18} \mathrm{O}_{\text {water }}$ displays the measured $\delta^{18} \mathrm{O}_{\text {seawater }}$ curve and hence, supports the use of a combined isotope and $\mathrm{Mg} / \mathrm{Ca}$ approach.

\section{Results and discussion}

\subsection{Hydrological conditions in the upper ocean water column}

At the time of multinet sampling (December 2012) at station SO22521 the mixed layer was characterized by a SST of $27.9^{\circ} \mathrm{C}$, a SSS of 35.5 , an oxygen concentration $>170 \mu \mathrm{mol} / \mathrm{l}$ and a $\delta^{18} \mathrm{O}_{\text {seawater }}$ of $+0.5 \%$ 。 (Fig. 2). The SST and SSS agree well with the long-term WOA13 dataset (Locarnini et al., 2013) showing a deep surface mixed layer (SML)

Table 2

Equations used to convert foraminiferal $\mathrm{Mg} / \mathrm{Ca}$ into temperatures and to calculate equilibrium $\delta^{18} \mathrm{O}_{\text {equilibrium. }}$.

\begin{tabular}{|c|c|c|c|c|c|}
\hline Species & Type of sample & Water mass & \multicolumn{2}{|l|}{ Equation } & Reference \\
\hline & & & \multicolumn{3}{|l|}{$\mathrm{Mg} / \mathrm{Ca}=\mathrm{B} * \exp (\mathrm{A} * \mathrm{~T})$} \\
\hline & & & B & \multicolumn{2}{|c|}{ A } \\
\hline G. ruber & Surface sediment $(0-1 \mathrm{~cm})$ & Sea-surface and sub-surface $(0-100 \mathrm{~m})$ & 0.40 & 0.09 & Regenberg et al. (2009) \\
\hline G. sacculifer & Surface sediment $(0-1 \mathrm{~cm})$ & Sea-surface and sub-surface $(0-100 \mathrm{~m})$ & 0.37 & 0.09 & Dekens et al. (2002) \\
\hline N. dutertrei & Surface sediment $(0-1 \mathrm{~cm})$ & Upper thermocline (100-200 m) & 0.065 & 0.065 & Regenberg et al. (2009) \\
\hline P. obliquiloculata & Sediment-trap & Upper thermocline (100-200 m) & 0.18 & 0.12 & Anand et al. (2003) \\
\hline \multirow[t]{5}{*}{ G. hexagonus } & Surface sediment $(0-1 \mathrm{~cm})$ & Sub-surface (300-500 m) & 0.52 & 0.10 & Elderfield and Ganssen (2000) \\
\hline & & & \multicolumn{3}{|c|}{$\begin{array}{l}\mathrm{T}=\mathrm{a}+\mathrm{b}\left(\delta^{18} \mathrm{O}_{\text {calcite }}-\delta^{18} \mathrm{O}_{\text {seawater }}\right)- \\
\mathrm{c}\left(\delta^{18} \mathrm{O}_{\text {calcite }}-\delta^{18} \mathrm{O}_{\text {seawater }}\right)^{2}\end{array}$} \\
\hline & & & b & c & \\
\hline & Inorganic & Sub-thermocline (300-500 m) & -4.64 & 0.09 & Kim and O'Neil (1997) \\
\hline & Living foraminifera & Sea-surface to upper thermocline $(0-200 \mathrm{~m})$ & -4.28 & 0.07 & Mulitza et al. (2004) \\
\hline
\end{tabular}


Table 3

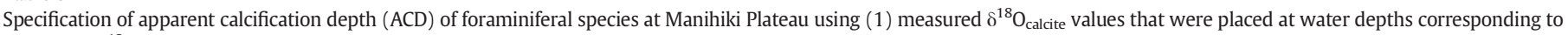

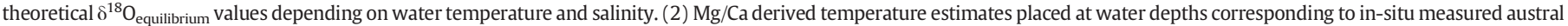
summer temperatures (Werner et al., 2013) and seasonal World Ocean Atlas 2013 temperature ranges (Locarnini et al., 2013). Each line represents one single analysed sample.

\begin{tabular}{|c|c|c|c|c|c|c|c|c|}
\hline \multirow{3}{*}{ Species } & \multicolumn{6}{|c|}{ ACD (m water depth) } & \multicolumn{2}{|c|}{$\begin{array}{l}\text { Combined isotope and } \\
\text { temperature ACD ( } \mathrm{m} \text { water depth) }\end{array}$} \\
\hline & \multirow[t]{2}{*}{$\begin{array}{l}\text { Using } \delta^{18} \mathrm{O}_{\mathrm{eq}} \\
\text { Dec. } 2012\end{array}$} & \multicolumn{2}{|c|}{ Using seasonal $\delta^{18} \mathrm{O}_{\mathrm{eq}}$} & \multirow[t]{2}{*}{$\begin{array}{l}\text { Using temperature during sampling } \\
\text { (Dec. 2012) }\end{array}$} & \multicolumn{2}{|c|}{ Using seasonal temperature } & \multirow[t]{2}{*}{ ACD range } & \multirow[t]{2}{*}{ Mean ACD } \\
\hline & & Shallowest & Deepest & & Shallowest & Deepest & & \\
\hline \multirow[t]{9}{*}{ G. ruber } & 152 & 106 & 126 & & & & & \\
\hline & 154 & 113 & 137 & & & & & \\
\hline & 77 & 65 & 66 & & & & & \\
\hline & 138 & 91 & 105 & & & & & \\
\hline & 124 & 85 & 96 & & & & & \\
\hline & & & & 136 & 92 & 109 & & \\
\hline & & & & 5 & 5 & 16 & & \\
\hline & & & & ACD (m water depth) & & & & \\
\hline & Mean isotope & CD: 109 & & Mean temperature ACD: 61 & & & $5-154$ & $95 \pm 44$ \\
\hline \multirow[t]{16}{*}{ G. sacculifer } & 151 & 101 & 118 & & & & & \\
\hline & 151 & 100 & 118 & & & & & \\
\hline & 151 & 98 & 115 & & & & & \\
\hline & 151 & 99 & 117 & & & & & \\
\hline & 161 & 140 & 156 & & & & & \\
\hline & 152 & 104 & 124 & & & & & \\
\hline & 141 & 93 & 107 & & & & & \\
\hline & 132 & 89 & 101 & & & & & \\
\hline & 159 & 135 & 154 & & & & & \\
\hline & 156 & 119 & 145 & & & & & \\
\hline & 154 & 115 & 140 & & & & & \\
\hline & & & & 141 & 100 & 112 & & \\
\hline & & & & 126 & 67 & 105 & & \\
\hline & & & & 5 & 5 & 5 & & \\
\hline & & & & ACD (m water depth) & & & & \\
\hline & Mean isotope & CD: 129 & & Mean temperature ACD: 74 & & & $5-161$ & $117 \pm 39$ \\
\hline \multirow[t]{5}{*}{ N. dutertrei } & 160 & 140 & 156 & & & & & \\
\hline & 154 & 115 & 140 & & & & & \\
\hline & 153 & 110 & 132 & & & & & \\
\hline & & & & $\begin{array}{l}154 \\
\text { ACD (m water depth) }\end{array}$ & 140 & 150 & & \\
\hline & Mean isotope & CD: 140 & & Mean temperature ACD: 148 & & & $110-160$ & $142 \pm 16$ \\
\hline \multirow[t]{12}{*}{ P. obliquiloculata } & 163 & 151 & 160 & & & & & \\
\hline & 166 & 154 & 164 & & & & & \\
\hline & 162 & 146 & 158 & & & & & \\
\hline & 168 & 156 & 166 & & & & & \\
\hline & 169 & 157 & 168 & & & & & \\
\hline & 167 & 154 & 164 & & & & & \\
\hline & 171 & 159 & 170 & & & & & \\
\hline & & & & 158 & 145 & 155 & & \\
\hline & & & & 159 & 146 & 156 & & \\
\hline & & & & 160 & 151 & 161 & & \\
\hline & & & & ACD (m water depth) & & & & \\
\hline & Mean isotope & CD: 162 & & Mean temperature ACD: 155 & & & $145-171$ & $159 \pm 7$ \\
\hline \multirow[t]{5}{*}{ G. hexagonus } & 431 & 427 & 435 & & & & $375-514$ & $450 \pm 46$ \\
\hline & 498 & 509 & 514 & & & & & \\
\hline & 467 & 469 & 473 & & & & & \\
\hline & & & & 375 & 396 & 403 & & \\
\hline & Mean isotope & CD: 469 & & Mean temperature ACD: 391 & & & & \\
\hline
\end{tabular}

extending to $105 \mathrm{~m}$ water depth, below which temperature decreases steadily. The main thermocline is located between 130 and $230 \mathrm{~m}$ water depth and reflects an overall temperature decline of $\sim 16{ }^{\circ} \mathrm{C}$ (from $28{ }^{\circ} \mathrm{C}$ to $\sim 12{ }^{\circ} \mathrm{C}$ ).

At the top of the thermocline, however, both temperature and salinity deviate from the long-term average (Fig. 2a, b). The temperatures are up to $2{ }^{\circ} \mathrm{C}$ warmer between 125 and $150 \mathrm{~m}$. Salinities are significantly reduced between 125 and $160 \mathrm{~m}$. These changes may indicate changes in the source area and speed of the EUC as a consequence of weaker trade winds in December 2012. In contrast, the comparison between

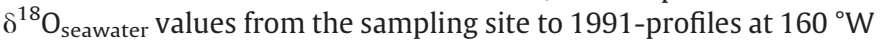
and $168^{\circ} \mathrm{W}$ (Schmidt et al., 1999) reveals up to $0.2 \%$. heavier values (Fig. 2c). As in the open ocean, $\delta^{18} \mathrm{O}_{\text {seawater }}$ is mainly affected by the evaporation/precipitation balance (Dansgaard, 1964) with heavier values attributed to higher evaporation, we assume an increase in evaporation probably related to stronger trade winds from 1991 until December 2012. This agrees with model experiments that show an acceleration of Pacific trade winds due to the intensification of the Walker circulation over the period 1992-2011 (McGregor et al., 2014). Consequently, it seems that over the last decade trade wind strength and hence evaporation increased, but in December 2012 wind strength dropped for a short time, leading to a decrease in upwelling and thus to warmer and less saline waters at the top of the thermocline. Further support comes from the equatorial Pacific Zonal Wind field models in November-December 2012 (NOAA, 2015b) and from the slightly increased Oceanic Niño Index $(\mathrm{ONI})$ that indicates a very weak El Niño $\left(\mathrm{ONI}>0.5^{\circ} \mathrm{C}\right)$ and consequently weaker prevailing winds (see also Section 1.1) (NOAA, 2015a).

Associated with the thermo- and halocline, oxygen concentrations decline in two steps, which points to two oxygen minima (OM) located at $\sim 180 \mathrm{~m}$ and $\sim 250 \mathrm{~m}$ (Fig. $2 \mathrm{~d}$ ). Possibly both OM belong to one 


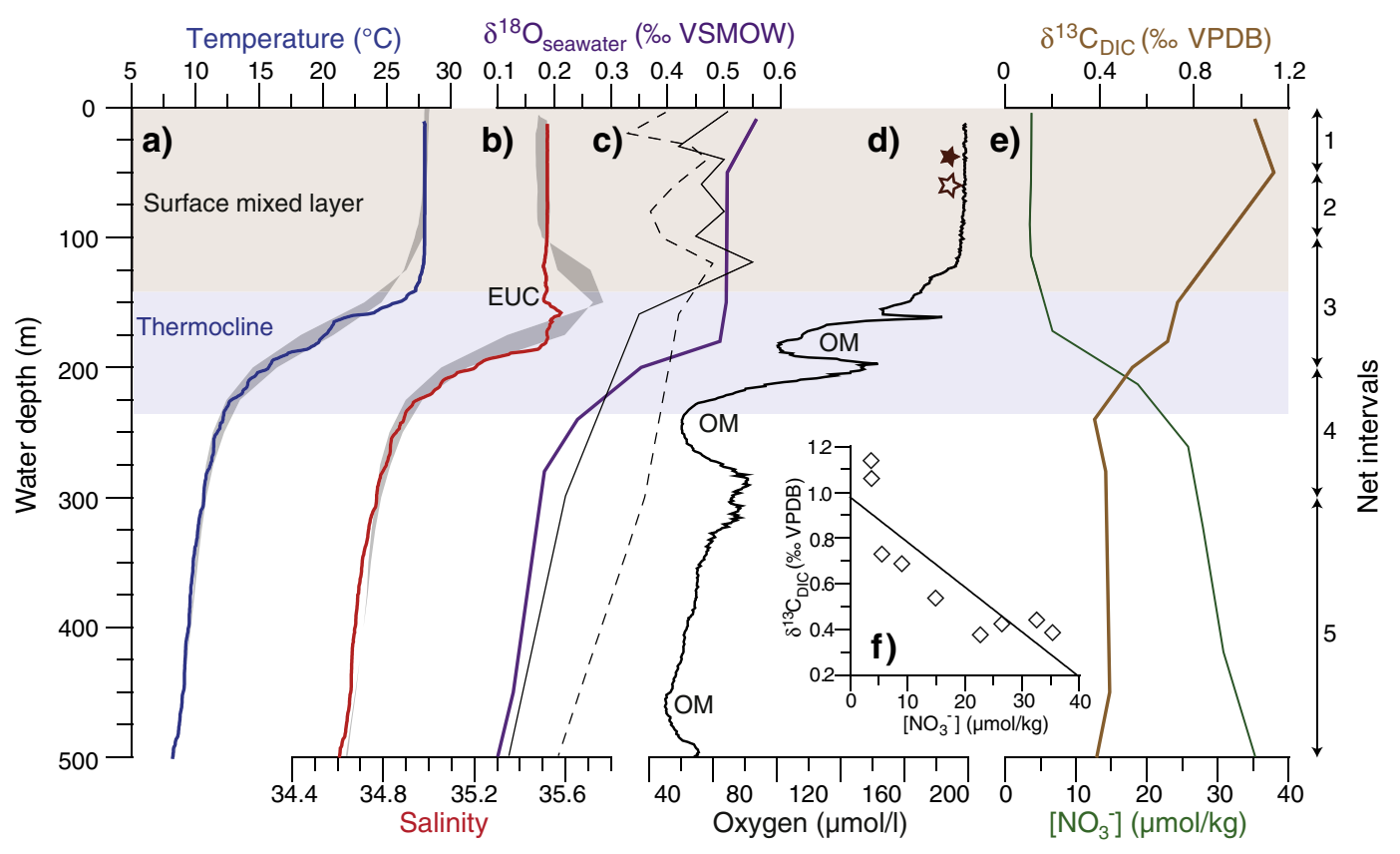

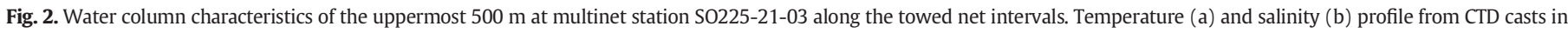

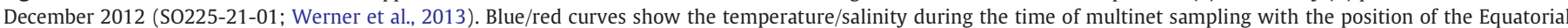

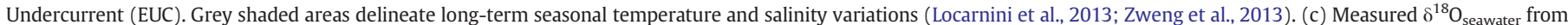

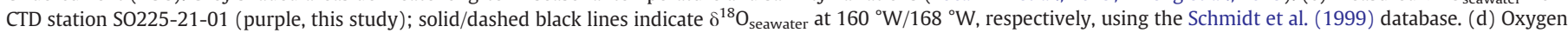

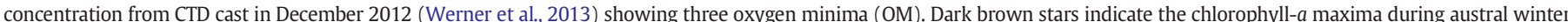

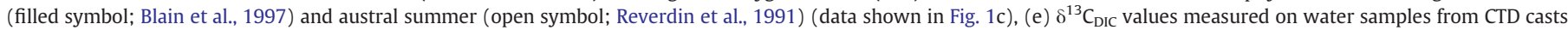

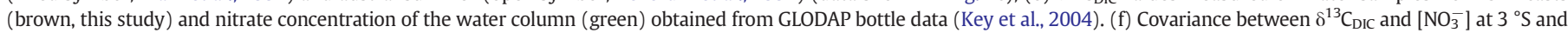

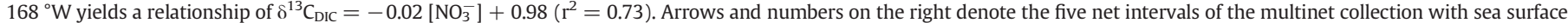

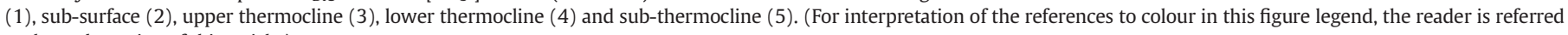
to the web version of this article.)

expansive OM that is separated by a chlorophyll maximum in which oxygen is produced. However, to verify this hypothesis a deeper chlorophyll- $a$ profile extending to at least $300 \mathrm{~m}$ water depth is needed. Oxygen concentrations further decline below the thermocline towards a less pronounced $\mathrm{OM}$ in $\sim 450 \mathrm{~m}$ with concentrations of $57 \mu \mathrm{mol} / \mathrm{l}$. The strongest OM in December 2012 (concentration of $44 \mu \mathrm{mol} / \mathrm{l}$ ) is located at $\sim 660 \mathrm{~m}$ water depth below the hauled nets.

At the multinet sampling site, the overall range in $\delta^{13} \mathrm{C}_{\mathrm{DIC}}$ is from $\sim 0.4 \%$ o to $\sim 1.1 \%$, achieving a maximum in the surface waters (Fig. $2 \mathrm{e}$ ). The $\delta^{13} C_{\text {DIC }}$ data start to decline below $\sim 50 \mathrm{~m}$ and gradually decrease throughout the thermocline in response to remineralisation processes and the release of ${ }^{12} \mathrm{C}$ to the ambient seawater. The overall shape of the $\delta^{13} C_{\text {DIC }}$ profile is anticorrelated to the GLODAP [ $\mathrm{NO}_{3}^{-}$] profile (Key et al., 2004). With increasing nitrate concentrations, the $\delta^{13} \mathrm{C}_{\mathrm{DIC}}$ values decrease simultaneously due to the concurrent uptake of ${ }^{12} \mathrm{C}$ and nutrients during photosynthesis. The slope of this relationship depends on the fractionation of $\delta^{13} \mathrm{C}$ during photosynthesis. Our $\delta^{13} \mathrm{C}_{\mathrm{DIC}}$ : $\left[\mathrm{NO}_{3}^{-}\right]$ comparison yield a relationship of: $\delta^{13} \mathrm{C}_{\mathrm{DIC}}=-0.02\left[\mathrm{NO}_{3}^{-}\right]+0.98$ $\left(r^{2}=0.73\right)$ (Fig. 2f).

\subsection{Vertical distribution of planktonic foraminifers in the water column}

A total number of 20 taxa have been identified in the net collection from the Manihiki Plateau of which 16 could be identified on the species level (Supplement Table S1). Most common and abundant species $(>10 \%)$ are: Globorotalia menardii (mean relative abundance (MRA) $22.7 \%$, range $7.8 \%-26.4 \%$ ), Pulleniatina obliquiloculata (MRA: 15.4\%, range 5.2-19.6\%), Globigerinita glutinata (MRA 13.8\%, range 5.7$30.1 \%$ ), Globigerinella spp. (MRA 12.8\%, range 3.6-16\%) and Globorotalia spp. (MRA 10\%, range 3.6-10.8\%). Less abundant species (2-10\%) are Globigerinoides sacculifer (MRA 7.2\%, range 3.6-9.8\%), Neogloboquadrina dutertrei (MRA 5.1\%, range 2.6-6.3\%), Globigerinoides ruber (white)
(MRA 2.9\%, range 0.8-5\%) and Globoquadrina conglomerata (MRA 2.1\%, range $1-2.8 \%$ ). All other taxa occur in very low abundances (MRA $<2 \%$ ). For further analyses, we selected four species often used in paleoceanographic research (G. ruber, G. sacculifer, N. dutertrei, and $P$. obliquiloculata, e.g., Spero et al., 2003; Kiefer et al., 2006; Pena et al., 2008; Leduc et al., 2009; Nürnberg et al., 2015; Rippert et al., 2015), although other species had a higher abundance in the water column during our expedition. The highest abundances (in \#/m $\mathrm{m}^{3}$ ) of the selected species were found between 0 and $100 \mathrm{~m}$ water depth (Fig. 3). This is the depth interval with highest chlorophyll- $a$ concentrations (Fig. 1c), supporting the idea that nutrient distribution mainly determines the vertical distribution of foraminiferal species (Hemleben et al., 1989; Schiebel et al., 2001; Schiebel and Hemleben, 2005).

Sediment trap and surface sediment studies from tropical areas indicate that G. sacculifer and G. ruber dominate the foraminiferal abundances with $>5 \%$ and $>10 \%$, respectively, with similar abundances in the Atlantic and Pacific for G. sacculifer ( 10\%) and higher abundances of G. ruber in the Atlantic compared to the Pacific ( 40 to $~ 18 \%$, respectively) (Thunell and Honjo, 1981; Ravelo et al., 1990; Kawahata et al., 2002; Schmuker and Schiebel, 2002; Yamasaki et al., 2008). Our MRAs, however, show abundances of these species of $<10 \%$ in December 2012. This is in agreement with sediment trap analyses from the West Caroline Basin (New Guinea) deployed over a one year interval that revealed a seasonal bias in foraminiferal shell flux with lowest fluxes for G. ruber and G. sacculifer in December (Kawahata et al., 2002). Further, our study site at the northernmost rim of the Manihiki Plateau is situated at the transition from the WPWP to the Pacific Equatorial Divergence (Le Borgne et al., 2002). High SSTs at the sampling site suggest the dominant influence from the WPWP. On the other hand, surface nitrate concentrations of $3.6 \pm 0.1 \mu \mathrm{mol} / \mathrm{kg}\left(168.7^{\circ} \mathrm{W},-3^{\circ} \mathrm{S}\right.$, $168^{\circ} \mathrm{W}$ ) (Key et al., 2004) are higher than nitrate concentrations typically characteristic for the WPWP $(<0.1 \mu \mathrm{mol} / \mathrm{kg}$ ) (Blanchot et al., 


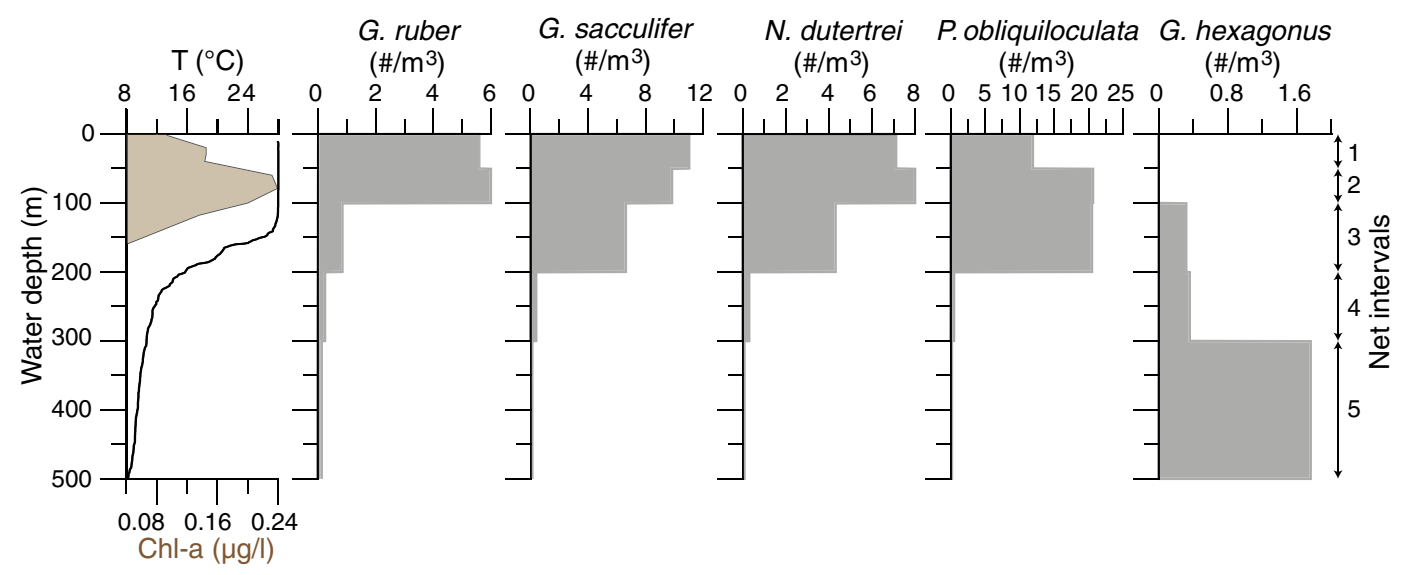

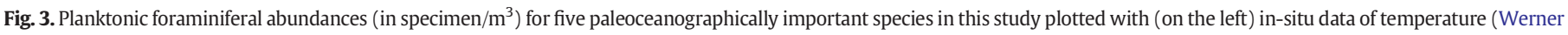

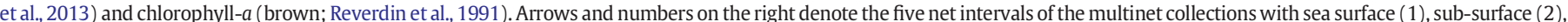

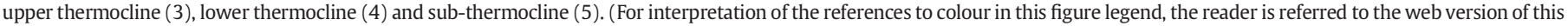
article.)

2001; Rafter and Sigman, 2015) and rather suggest a presumably slight increased influence of the Pacific Equatorial Divergence. Additionally, repeated station analyses on nitrate concentrations along the equator also reveal increasing nitrate concentrations at the base of the SML during austral summer (Rafter and Sigman, 2015). Since the hydrographic data record a general decrease in upwelling (Fig. 2), higher nutrient concentrations probably result from increased diapycnal mixing (Rafter and Sigman, 2015). As a consequence of these higher nutrient concentrations primary production was increased, which can be seen in the higher chlorophyll- $a$ concentrations determined from Ocean Colour Data during sampling (NASA Ocean Biology, 2015). The resulting higher amounts of nutrients and food most likely explain the relatively high abundances of G. menardii, P. obliquiloculata, and G. glutinata, which are often associated within or are found at the border of fertile tropical areas (Watkins et al., 1998). A higher abundance of these species, in turn, will compete with G. ruber and G. sacculifer, and thereby, decrease their abundance as seen in our multinet analyses.

Despite the low MRA of 1.7\%, G. hexagonus dominates the foraminiferal assemblage with roughly $45 \%$ at $300-500 \mathrm{~m}$ water depth (Supplement Table S1). Therefore, we included this species in our analyses as well. The high numbers below $300 \mathrm{~m}$ demonstrate its adaptation to deeper, colder waters. To date, there is only sparse information about the seasonal and the reproductive cycle of this species. Time series sediment traps from the Peru-Chile Current indicate that in contrast to most other deepdwelling species, G. hexagonus is present year-round (Marchant et al., 1998). Taking the preference for an ecologically more uniform habitat with smaller seasonal variations (compared to the shallow ocean) into account, the reproductive cycle of $G$. hexagonus could be similar to other deep-dwelling species (possibly once per year; Schiebel and Hemleben, 2005). However, more studies on their depth and seasonal distribution as well as their ecology are required to infer a specific calcification depth.

\subsection{Foraminiferal apparent calcification depth}

By combining the isotope-based ACDs (Fig. 4a) with the $\mathrm{Mg} / \mathrm{Ca}$-based ACDs (Fig. 4b), we can reliably infer the overall range of species-specific ACDs (Fig. 4c, Table 3). Relative ACDs within a foraminifera assemblage point to G. ruber as the shallowest dweller, followed with increasing depth by G. sacculifer, N. dutertrei, P. obliquiloculata and G. hexagonus being the deepest dwelling species. The ACDs of these species are similar to that shown for other ocean basins (e.g., Ravelo and Fairbanks, 1992; Dekens et al., 2002; Steph et al., 2009; Regenberg et al., 2009; Rincón-Martínez et al., 2011; Birch et al., 2013; Lynch-Stieglitz et al., 2015). However, absolute values differ between and within ocean basins. Furthermore, a large discrepancy between the $\delta^{18} \mathrm{O}$-derived ACDs and the
$\mathrm{Mg} / \mathrm{Ca}$ temperature-derived ACDs can sometimes be observed. This is possibly the result of a combination of various effects:

(1) $\mathrm{Mg} / \mathrm{Ca}$ was measured on different and sometimes larger tests than tests used for isotope measurements due to logistical obstacles (Table 1). The test sizes used for the $\mathrm{Mg} / \mathrm{Ca}$ ablation of this study are unusually large for $\mathrm{Mg} / \mathrm{Ca}$ analyses that often concentrate on test sizes between 250 and $500 \mu \mathrm{m}$ (e.g., Dekens et al., 2002; Anand et al., 2003). However, as we were limited by the amount of foraminiferal tests within the net samples for the measurements, we had to enlarge the size fraction. Studies have shown that there might be a size-related control on the incorporation of $\mathrm{Mg}$ into the foraminiferal shell with decreasing $\mathrm{Mg} / \mathrm{Ca}$ values with increasing size possibly due to the additional formation of gametogenic calcite (Elderfield et al., 2002; Ni et al., 2007; Friedrich et al., 2012). However, it was also shown that the amount of gametogenic calcite was constant (ca. $4 \mu \mathrm{g}$ ) independent of size (Hamilton et al., 2008). The fact that the foraminifera we analysed often still had their spines or remains thereof indicate that gametonenetic calcite was not present. Nonetheless, isotope and $\mathrm{Mg} / \mathrm{Ca}$ samples from a similar size range (Table 1) show comparable ACDs (Table 3 ) and thus, we consider the large size $\mathrm{Mg} / \mathrm{Ca}$-derived $\mathrm{ACD}$ estimations as reliable.

(2) For laser ablation, only one single foraminiferal test was needed, but for isotope measurements more than one shell per species were used (Table 1). Thereby, the inter-sample variability was lower in isotope measurements, which could have led to less variability in ACD estimates.

(3) The $\delta^{18} \mathrm{O}$-paleotemperature equations applied in this study provide an additional reason for varying ACDs between the measurements. This holds true especially for mixed layer species as they are exposed to greater variability of water characteristics and thus, tend to have more ecology-related chemical effects. $\mathrm{Mg} / \mathrm{Ca}$ was converted into temperatures using species-specific calibration equations (Table 2). For the determination of $\delta^{18} \mathrm{O}_{\text {equilibrium, we }}$ used the general equations of Mulitza et al. (2004) that was developed using four foraminiferal species reflecting both surface and sub-surface species and the equation of Kim and O'Neil (1997) that was derived from inorganic calcite (see Section 2.5).

\subsubsection{Apparent calcification depths of G. ruber and G. sacculifer}

At multinet station SO225-21-3, G. ruber and G. sacculifer calcified over a broad depth range ranging from the sea surface down to 
a)

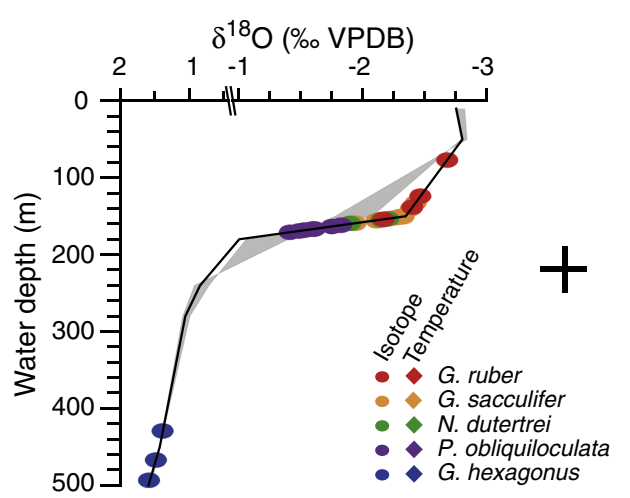

b) $\mathrm{Mg} /$ Ca-based $\mathrm{ACD}$

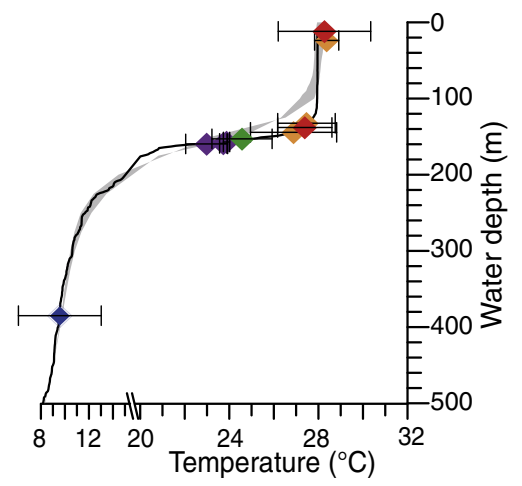

c) combined ACD

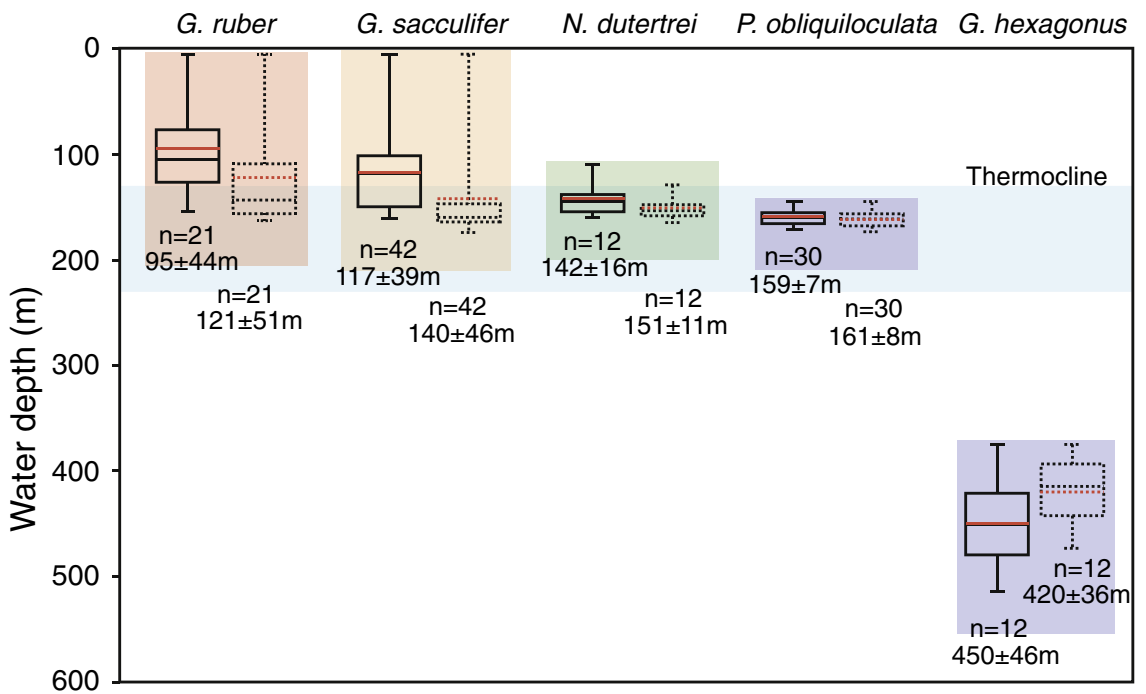

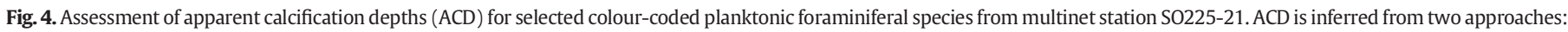

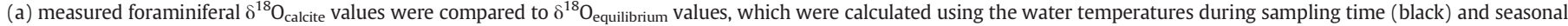

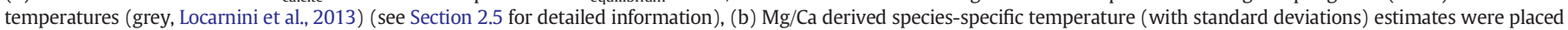

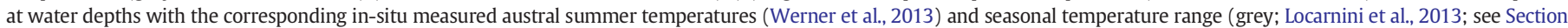

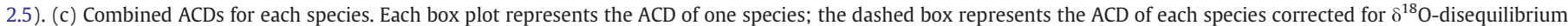

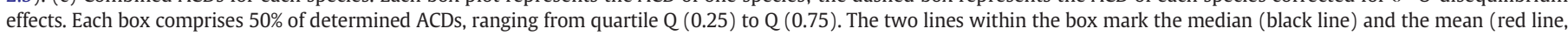

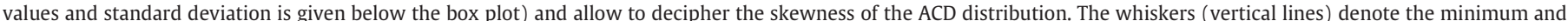

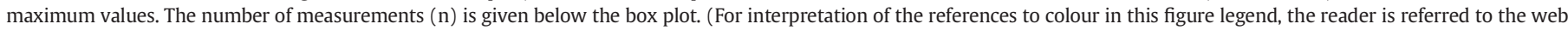
version of this article.)

160 m water depth (Fig. 4, Table 3). This mirrors the thick SML in the WPWP and supports the notion of these species being surface-dwellers (Fairbanks et al., 1982; Bé et al., 1985; Ravelo and Fairbanks, 1992; Watkins et al., 1996; Steph et al., 2009; Rincón-Martínez et al., 2011; Lynch-Stieglitz et al., 2015; Nürnberg et al., 2015).

Most studies point to a habitat of $G$. ruber within the first $30 \mathrm{~m}$ of the water column (Fairbanks et al., 1982; Bé et al., 1985; Faul et al., 2000; Mohtadi et al., 2009) and G. sacculifer within the first $80 \mathrm{~m}$ (Fairbanks et al., 1982; Bé et al., 1985; Watkins et al., 1996; Steph et al., 2009). Our study revealed that in December 2012, highest G. ruber abundances were found in the nets of 50-100 m (Fig. 3) and the ACD estimate showed that $50 \%$ of G. ruber calcified between 70 and $125 \mathrm{~m}$ (Fig. 4). The depth agrees well to the optimum temperature preference of $\sim 27^{\circ} \mathrm{C}$ (Mulitza et al., 1998). Various studies point towards varying calcification depths for different morphotypes of G. ruber (Wang, 2000; Steinke et al., 2005; Kuroyanagi et al., 2008) and a seasonal bias in G. ruber abundances (e.g., Kawahata et al., 2002; Stott et al., 2002; Lin et al., 2004; Žarić et al., 2005). However, with the present dataset we are not able to address this issue.

The determined ACDs of G. sacculifer are commonly deeper than the ACDs of G. ruber (Table 3), which corroborates Central Pacific core-top studies that recorded heavier $\delta^{18} \mathrm{O}$ values and thus, a generally deeper ACD for G. sacculifer in comparison to G. ruber (Lynch-Stieglitz et al., 2015). Furthermore, a plankton tow study from the South Atlantic revealed that in areas with a thick mixed layer, G. sacculifer often exhibits deeper ACDs than G. ruber, whereas in areas with a shallow thermocline, both species dwell at similar depths (Kemle-von Mücke and Oberhänsli, 1999). This observation agrees with the slightly cooler optimum temperature range in G. sacculifer compared to G. ruber (Bijma et al., 1990). Fifty percent of $G$. sacculifer's ACDs fall in the depth range between 100 and $150 \mathrm{~m}$, which is deeper than the highest abundances of this species, which is found in the nets in $0-50 \mathrm{~m}$. However, it has been shown that $G$. sacculifer migrates to deeper water depths later in its ontogeny (Bijma and Hemleben, 1994). As small individuals 
outnumber larger specimens due to the high mortality rate, highest total abundances of this species are much shallower than ACDs determined on larger specimens (Hemleben and Bijma, 1994). Furthermore, a stratified plankton-tow study from the Red Sea showed that specimens from the 350-500 $\mu \mathrm{m}$ size fraction accumulate in a narrow depth range (Bijma and Hemleben, 1994) similar to our results. This also explains why tests selected from deeper habitats depths (100$200 \mathrm{~m}$ for G. sacculifer and 300-500 m for G. ruber) also record ACDs within the SML and not from the net depth range they were selected from (Tables 1 and 3). Hence, calcification of these tests happened within the SML. Just before net sampling, these specimens possibly died and sank down to the depth in which we caught them.

The SML at the study site extended deeper than the SML recorded by the long-term average at the same position (Fig. 2a). This could explain why the ACDs of G. ruber and G. sacculifer are deeper than ACDs estimated from seasonally varying temperatures (Table 3). Using seasonal temperatures, both species record shallowest ACDs in austral winter and deepest during austral summer, possibly also as a result of changes in the depth of the DCM (Fig. 1c). Despite the fact that both species host symbionts and are therefore highly dependent on light availability (Hemleben and Bijma, 1994; Schiebel and Hemleben, 2005), the data suggest that these species possibly descend to deeper waters in oligotrophic environments to exploit the DCM for food as proposed by e.g., Fairbanks et al. (1982), Schiebel et al. (2001), Schiebel and Hemleben (2005), and Steph et al. (2009).

Species-specific vital-effects can alter the ACD assessment, as the deviation from isotopic equilibrium might result in too-deep or too-shallow calculated ACDs. In symbiont-bearing species vital effects have been shown to be large (Niebler et al., 1999). Correcting the measured $\delta^{18} \mathrm{O}_{\text {calcite }}$ data for a disequilibrium of $-0.4 \%$ and $-0.6 \%$ (Niebler et al., 1999) for G. ruber and G. sacculifer, respectively, results in $<23 \%$ deeper ACDs for G. ruber and $<10 \%$ deeper ACDs for G. sacculifer that would point to a calcification within the thermocline (Fig. 4, Supplement Table S3). However, as the highest abundances of these species were found in surface waters similar to other studies, we find these deep vital-corrected ACDs rather unlikely.

In summary, it seems that ACDs determined by using measured temperatures during sampling (December 2012) or seasonal temperatures do not differ substantially. However, using vital-corrected ACDs might lead to different results as foraminifera might be placed into different water masses. Thus, to make realistic ACD-reconstructions, one needs to consider the combination of determined ACD, the local hydrography, local foraminiferal abundance data, and to take into account that the last few chambers determine the majority of the chemical signature of the shell.

\subsubsection{Apparent calcification depths of N. dutertrei and P. obliquiloculata}

The ACD assessment at the sampling site for $N$. dutertrei and $P$. obliquiloculata reveals calcification in a very narrow depth range at the top and within the upper thermocline, which is in broad agreement with other ACD studies (e.g., Ravelo and Fairbanks, 1992; Faul et al., 2000; Regenberg et al., 2009; Steph et al., 2009). The mean ACD of $\sim 140 \pm 16 \mathrm{~m}$ (N. dutertrei) and $\sim 160 \pm 7 \mathrm{~m}$ (P. obliquiloculata) (Table 3 ) are somewhat deeper than in other studies, possibly due to the comparatively deep thermocline in the western equatorial Pacific. As the thermocline was warmer during sampling than the long-term average (see Section 3.1), we also calculated the ACDs using seasonal temperature data (Locarnini et al., 2013). The estimated seasonal ACDs are, however, within the ACD range determined by the combined stable isotope and temperature approach (Table 3 ). Furthermore, both species are also affected by isotopic disequilibrium. Correcting the measured $\delta^{18} \mathrm{O}_{\text {calcite }}$ values of $N$. dutertrei and $P$. obliquiloculata for disequilibrium of $-0.2 \%$ and $-0.1 \%$ ( Niebler et al., 1999 ), respectively, only small shifts towards deeper water depths of $<3 \%$ for $N$. dutertrei and $<1 \%$ for P. obliquiloculata occur (Fig. 4; Supplement Table S3).
The net collection from this study has the highest abundance of $N$. dutertrei in 50-100 m water depth within the DCM (Fig. 3). This agrees with the general view that $N$. dutertrei inhabits a shallow water depth close to the DCM (Fairbanks et al., 1982; Bé et al., 1985; Hemleben et al., 1989; Ravelo and Fairbanks, 1992; Dekens et al., 2002; Schmuker and Schiebel, 2002; Sadekov et al., 2013). Our study site at the Manihiki Plateau is at the border of the Pacific Equatorial Divergence (see also Section 3.2). As the longitudinal transition between WPWP and Pacific Equatorial Divergence varies between $\sim 150{ }^{\circ} \mathrm{E}$ and $150{ }^{\circ} \mathrm{W}$ (Le Borgne et al., 2002) depending on the wind strength and surface currents, it is expected that $N$. dutertrei changes its habitat and calcification depth depending on the prevailing environmental setting. This is supported by calcification-depth studies from the highly dynamic eastern equatorial Pacific that reveal variable habitats depending on the strength of the coastal upwelling with shallower habitats in cases of strong upwelling (Nürnberg et al., 2015, and discussion therein).

Our ACD estimates for P. obliquiloculata correspond well with the observations: all specimens, regardless of the net depth the foraminifera were taken from, calcified between 145 and $170 \mathrm{~m}$ and highest abundances of adult specimen were found in nets of 100-200 m water depths. Consequently, this species might be more appropriate for thermocline reconstructions. This is in line with previous studies showing that P. obliquiloculata is associated with the base of the upper thermocline in other ocean basins (e.g., Ravelo and Fairbanks, 1992; Faul et al., 2000; Mohtadi et al., 2009; Rincón-Martínez et al., 2011).

\subsubsection{Apparent calcification depths of $G$. hexagonus}

Both $\delta^{18} \mathrm{O}$-derived and $\mathrm{Mg} / \mathrm{Ca}$-derived ACDs display a deep habitat for $G$. hexagonus ranging from 375 to 515 m water depth (mean ACD: $450 \pm 46 \mathrm{~m}$ ) (Fig. 4, Table 3) below the thermocline. As seasonal temperature variations are $<0.4{ }^{\circ} \mathrm{C}$ in $300-500 \mathrm{~m}$ water depth, the ACD of $G$. hexagonus varies by maximal $30 \mathrm{~m}$. Most deep-dwelling foraminifera calcify close to isotopic equilibrium with small positive deviations (Niebler et al., 1999). Applying a $+0.1 \%$ o disequilibrium-correction to the $\delta^{18} \mathrm{O}_{\text {calcite }}$ values (Supplement Table S3) results in an up to $30 \mathrm{~m}$ shallower ACD, which is still clearly below the thermocline (Fig. 4). Overall, the assessed ACDs correspond well to the highest abundances from the net collection in 300-500 m water depth (Fig. 3).

Depth assignments from other studies are rare, as this species is endemic for the Indo-Pacific (Schiebel and Hemleben, 2005) and hardly ever exceeds a relative abundance of $2 \%$ in sediment assemblages (Beiersdorf et al., 1995; Hilbrecht, 1996). Our depth assessment, nevertheless, is similar to a study from the North Pacific with an estimated calcification depth of 330-390 m below the thermocline (Ortiz et al., 1996). However, our estimated ACD is deeper than the calcification depth reported from a core-top study from the western tropical Indian Ocean that places the calcification depth between 100 and $160 \mathrm{~m}$, i.e. within the mid-thermocline (Birch et al., 2013). These differences are probably the result of an interaction of four different effects:

(1) In the Indian Ocean, Birch et al. (2013) used a different size window ranging from 125 to $300 \mu \mathrm{m}$, whereas the test selected for this study range from 250 to $400 \mu \mathrm{m}$. Although smaller individuals often inhabit shallower waters than larger individuals (Fairbanks et al., 1982; Bijma and Hemleben, 1994; Kroon and Darling, 1995), our smallest size fraction still records far deeper habitats than largest specimen derived from Indian Ocean samples. Thus, the size effect on the different ACDs is assumed to be rather small.

(2) Birch et al. (2013) applied the paleotemperature equation of Erez and Luz (1983), which was calibrated using symbiont-bearing G. sacculifer. As G. hexagonus does not harbour symbionts (Parker, 1962), this symbiotic equation may result in erroneous temperatures. Symbionts increase ambient $\mathrm{pH}$ and $\left[\mathrm{CO}_{3}^{2-}\right]$ and hence decrease shell $\delta^{18} \mathrm{O}$ (Spero et al., 1997; Bijma et al., 1999), leading to an over-estimation of the real calcification temperature and hence would infer a calcification depth that is too shallow. By 
recalculating the ACD of G. hexagonus in the Indian Ocean with the equation by Kim and O'Neil (1997), the resulting ACD is deeper, between 110 and $180 \mathrm{~m}$. Nevertheless, this re-calculated ACD still lies within the western tropical Indian Ocean thermocline, highlighting the need for further explanations for varying ACDs of $G$. hexagonus.

(3) Ortiz et al. (1996) argue that G. hexagonus is a sub-thermocline species well adapted to its deep habitat, which is associated with the NPIW in the North Pacific. This water mass is characterized by elevated nutrient and particulate organic matter concentrations (e.g., Yamanaka and Tajika, 1996; Sarmiento et al., 2004). In contrast, sub-thermocline Indian Ocean water masses are less nutrient-rich than in the North Pacific. Furthermore, deep-dwelling (non-spinose) foraminifera such as Globorotalia tuncatulinoides or Globorotalia hirsuta are mainly herbivores (Hemleben et al., 1989; Schiebel and Hemleben, 2005). The sub-thermocline species Globorotalia scitula, for example, feeds on detrital, particulate organic material (Itou et al., 2001). As G. hexagonus inhabits a similar depth range to that of $G$. tuncatulinoides and G. scitula, we hypothesize that $G$. hexagonus is also a herbivore, feeding on particulate organic material. Consequently, G. hexagonus possibly calcifies in shallower water masses in the western Indian Ocean within the thermocline, where nutrients and particulate organic material accumulate. At our sampling site, the majority of Pacific equatorial sub-surface waters originate from outside the tropics and feed the equatorial sub-surface current system. The ACD determined for $G$. hexagonus corresponds to the depth of the Tsuchiya Jets that transport nutrients and particulate organic material originating in the extratropical regions along the equatorial Pacific (Fig. 1a; Johnson and Moore, 1997; Rowe et al., 2000). Thus, we conclude, that $G$. hexagonus favours water masses enriched in nutrients.

(4) Another important factor might be the insensitivity of G. hexagonus to changing oxygen concentrations in the water column (Birch et al., 2013). In the Indian Ocean, G. hexagonus calcifies in relatively low oxygen concentrations of $100-130 \mu \mathrm{mol} / \mathrm{kg}$, just above the OM (Birch et al., 2013). Similarly, at our sampling site, the ACDs in 375-500 $\mathrm{m}$ water depth correspond to decreasing oxygen concentrations $(\sim 60 \mu \mathrm{mol} / \mathrm{kg})$ (Fig. $2 \mathrm{~d})$ towards the OM at $450 \mathrm{~m}$ water depth. Hence it seems, that $G$. hexagonus prefers to calcify in cool, oxygen-depleted and nutrient-rich water masses and consequently, might be most suitable for reconstructing the variability in extratropical nutrient inflow into the equatorial current system.

\subsection{Foraminiferal carbon isotope disequilibrium}

In order to evaluate modern species-specific $\delta^{13} \mathrm{C}$-disequilibrium effects at certain growth stages, we measured the $\delta^{13} C_{\text {calcite }}$ values on various size fractions. The overall $\delta^{13} \mathrm{C}_{\text {calcite }}$ values range from $-0.14 \%$ in $N$. dutertrei to a maximum value of $+1.53 \%$ o in G. sacculifer (Fig. 5 , Table 4 ). Generally, deeper dwelling species record lower $\delta^{13} C_{\text {calcite values (con- }}$ comitant with higher $\delta^{18} \mathrm{O}_{\text {calcite }}$ values) than SML species. A variety of parameters including algal photosynthesis (Bé et al., 1982; Hemleben et al., 1989), metabolic fractionation (Wefer and Berger, 1991; Kroon and Darling, 1995; Spero et al., 1997), food availability (Spero et al., 1991; Ortiz et al., 1996), and carbonate chemistry of the seawater (Spero et al., 1997; Bijma et al., 1999) influence foraminiferal $\delta^{13} C_{\text {calcite }}$ values. Using the determined ACDs in which $50 \%$ of the species calcify (between quartile Q.25 and Q.75) (Fig. 4c), we attempted to infer the species-specific $\delta^{13} \mathrm{C}$-disequilibrium from ambient seawater at the study site. We did not determine the carbonate chemistry at the study site and hence, we cannot correct for the carbonate ion effect. Nevertheless, the measured $\delta^{13} \mathrm{C}_{\text {calcite }}$ reveals a distinct size-dependent deviation from $\delta{ }^{13} \mathrm{C}_{\mathrm{DIC}}$ values that generally agrees with other studies, such as

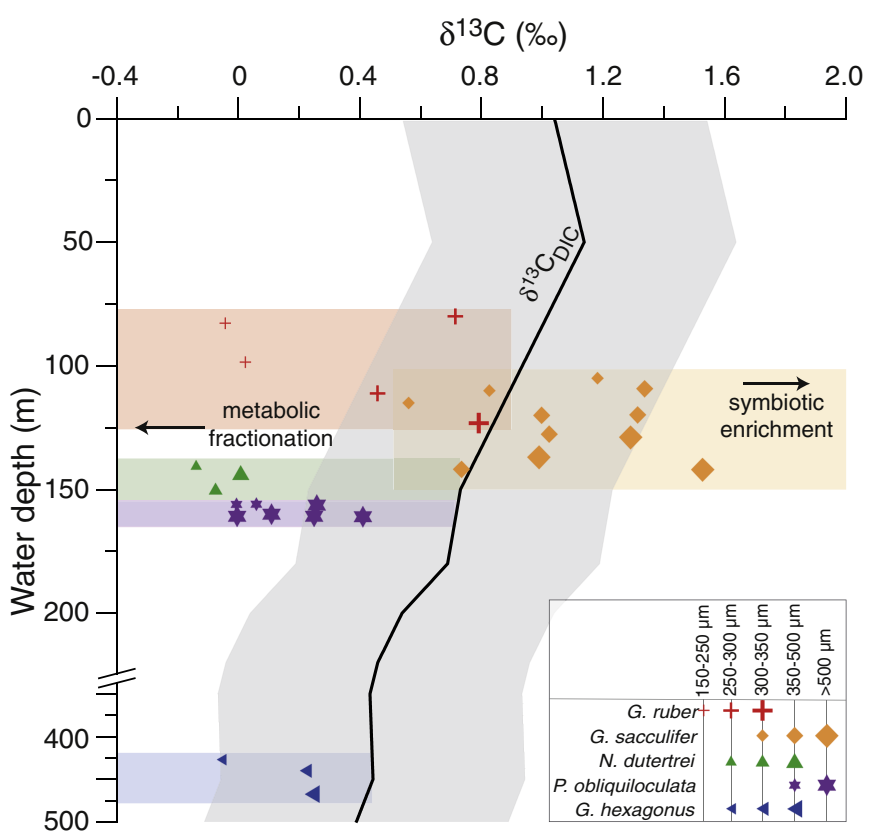

Fig. 5. Measured $\delta^{13} \mathrm{C}_{\text {calcite }}$ of selected living planktonic foraminifera in comparison to the in-situ measured $\delta^{13} C_{\text {DIC }}$ (black line) measured at multinet station SO225-21-3. Each symbol corresponds to a single species. The size of the symbol characterizes the specific test-size spectrum. Instrumental standard deviation is smaller than symbol sizes $( \pm 0.01 \%$ ), therefore not shown. Coloured-boxes illustrate the depths at which $50 \%$ of each species calcify (Fig. 4c). Values more negative than the equilibrium line are mostly affected by metabolism and respired light carbon, more positive values are possibly affected by symbiotic activity. Grey shaded area represents the $\pm 0.5 \%$ o inter-sample

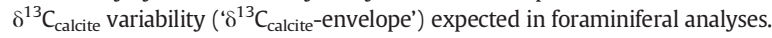

Oppo and Fairbanks (1989), Spero et al. (1991), Spero and Lea (1993), Kroon and Darling (1995), and Birch et al. (2013). The offset from ambient seawater for most species is even more pronounced than the added $\pm 0.5 \% \circ \delta{ }^{13} \mathrm{C}$-uncertainty (the ' $\delta{ }^{13} \mathrm{C}$-envelope') that might be expected in measured foraminiferal values to account for inter-sample variability expected in foraminiferal analysis (Birch et al., 2013). We also used 'vital-effect' corrected ACDs for the $\delta^{13} \mathrm{C}$-disequilibrium assessment. However, following this approach only results in little, if any, change in the ACD of the respective species (Table 4).

Large individuals of symbiont-bearing G. ruber and G. sacculifer are influenced by algal photosymbiosis. The symbionts preferentially incorporate light carbon into the organic matter leaving the microenvironment the foraminifera calcifies from enriched in ${ }^{13} \mathrm{C}$. Hence, ${ }^{13} \mathrm{C}$ enriched chambers are produced (Spero and Lea, 1993). Since the symbiont density increases with shell size (Spero and Parker, 1985), the $\delta$ ${ }^{13} \mathrm{C}_{\text {calcite }}$ values become more positively offset from ambient seawater $\delta^{13} C_{\text {DIC }}$ with up to $+0.8 \%$ in G. sacculifer. However, small individuals of SML and thermocline species have a large surface-to-volume ratio, tend to grow more rapidly, and possibly show a larger impact of depleted, respired $\mathrm{CO}_{2}$ due to higher metabolic activity (Berger et al., 1978; Wefer and Berger, 1991; Spero et al., 1997). As a result, foraminiferal $\delta$ ${ }^{13} \mathrm{C}_{\text {calcite }}$ is often negatively offset from equilibrium by up to $-1.1 \%$ (in G. ruber) (Table 4). As an individual grows, the influence of symbiontisotopic fractionation increases and dominates over the impact of respiration (Berger et al., 1978; Wefer and Berger, 1991; Spero et al., 1997).

Deep-dwelling asymbiotic $G$. hexagonus generally reveals a disequilibrium fractionation of $\leq 0.5 \%$, which is in the range of the $\delta^{13} \mathrm{C}_{\mathrm{DIC}}$-uncertainty. Only small tests of this species are slightly negatively depleted in $\delta^{13} C_{\text {calcite, }}$ probably due low metabolic rates as a consequence of low temperatures. Nevertheless, the near-equilibrium calcification is supported by a study from the tropical Indian Ocean (Birch et al., 2013), highlighting $G$. hexagonus as a reliable recorder of $\delta^{13} \mathrm{C}$ in subsurface water masses. 
Table 4

Foraminiferal $\delta{ }^{13} \mathrm{C}_{\text {calcite }}$ values with the determined $\delta^{13} \mathrm{C}$-disequilibrium and $\delta{ }^{13} \mathrm{C}$-disequilibrium values using vital-corrected ACDs. Each line represents one measurement of the respective species.

\begin{tabular}{|c|c|c|c|c|c|}
\hline Species & $\begin{array}{l}\text { Shell size } \\
\text { (range in } \\
\mu \mathrm{m} \text { ) }\end{array}$ & $\begin{array}{l}\text { Number } \\
\text { of tests } \\
\text { measured }\end{array}$ & $\begin{array}{l}\delta^{13} C_{\text {calcite }} \\
\text { (\%०) }\end{array}$ & $\begin{array}{l}\text { Disequilibrium } \\
(\%)\end{array}$ & $\begin{array}{l}\text { Disequilibrium } \\
\text { 'vital-corrected' } \\
(\%)\end{array}$ \\
\hline \multirow[t]{5}{*}{ G. ruber } & $150-250$ & 18 & -0.04 & -1.1 & -0.9 \\
\hline & $150-250$ & 17 & 0.02 & -1.0 & -0.9 \\
\hline & $250-300$ & 11 & 0.71 & -0.3 & -0.2 \\
\hline & $250-300$ & 14 & 0.46 & -0.6 & -0.4 \\
\hline & $300-350$ & 9 & 0.79 & -0.2 & -0.1 \\
\hline \multirow[t]{11}{*}{ G. sacculifer } & $300-350$ & 7 & 1.18 & 0.5 & 0.5 \\
\hline & $300-350$ & 5 & 0.83 & -0.1 & 0.1 \\
\hline & $300-350$ & 6 & 0.56 & -0.4 & -0.2 \\
\hline & $350-500$ & 4 & 1.31 & 0.6 & 0.6 \\
\hline & $350-500$ & 4 & 1.00 & 0.3 & 0.3 \\
\hline & $350-500$ & 4 & 1.34 & 0.6 & 0.6 \\
\hline & $350-500$ & 5 & 1.02 & 0.3 & 0.3 \\
\hline & $350-500$ & 5 & 0.73 & -0.2 & -0.01 \\
\hline & $>500$ & 2 & 1.53 & 0.8 & 0.8 \\
\hline & $>500$ & 3 & 0.99 & 0.3 & 0.3 \\
\hline & $>500$ & 2 & 1.29 & 0.6 & 0.6 \\
\hline \multirow[t]{3}{*}{ N. dutertrei } & $250-300$ & 12 & -0.14 & -0.9 & -0.9 \\
\hline & $300-350$ & 9 & -0.08 & -0.9 & -0.8 \\
\hline & $350-500$ & 6 & 0.03 & -0.8 & -0.7 \\
\hline \multirow[t]{7}{*}{ P. obliquiloculata } & $350-500$ & 4 & 0.06 & -0.7 & -0.7 \\
\hline & $350-500$ & 4 & -0.01 & -0.7 & -0.7 \\
\hline & $>500$ & 2 & -0.01 & -0.7 & -0.7 \\
\hline & $>500$ & 2 & 0.26 & -0.5 & -0.5 \\
\hline & $>500$ & 2 & 0.25 & -0.5 & -0.5 \\
\hline & $>500$ & 2 & 0.11 & -0.6 & -0.6 \\
\hline & $>500$ & 2 & 0.41 & -0.3 & -0.3 \\
\hline \multirow[t]{3}{*}{ G. hexagonus } & $250-300$ & 10 & -0.06 & -0.5 & -0.5 \\
\hline & $300-350$ & 9 & 0.22 & -0.2 & -0.2 \\
\hline & $350-500$ & 6 & 0.24 & -0.2 & -0.2 \\
\hline
\end{tabular}

\section{Conclusions}

The quality of paleoceanographic reconstructions of upper-ocean water mass conditions is tied to our precise knowledge of the ACDs of the studied foraminiferal species. The comparison between $\delta^{18} \mathrm{O}_{\text {calcite }}$ and $\mathrm{Mg} / \mathrm{Ca}$-derived temperatures measured on five living planktonic species with in-situ physical and chemical water mass properties enables us to enhance our knowledge about the species-specific ACDs.

The WPWP experiences a pronounced year-round thick SML that extends still deeper during December 2012 down to 130 m water depth. Determined ACDs of symbiont-bearing species G. ruber and G. sacculifer using both seasonal temperature data and temperatures during sampling indicate mean calcification depth of $\sim 95 \mathrm{~m}$ and $\sim 120 \mathrm{~m}$, respectively, corresponding to the base of the SML. These ACDs are deeper than in other ocean basins due to the hydrographic conditions of the WPWP, and the optimum temperature preference of these foraminifera. As vital effects further affect symbiont-bearing species, a combined approach of foraminiferal abundances, determined ACDs and hydrography provides most reliable ACD reconstructions.

Below the SML $N$. dutertrei and P. obliquiloculata calcified in a very narrow depth range of 140-160 m, corresponding to the top and within the thermocline, regardless of the temperature data used (seasonal or during sampling). The same holds true for vital effect corrections. The agreement between our ACD of $P$. obliquiloculata and other studies, suggest that $P$. obliquiloculata is most suitable for thermocline reconstructions.

The species $G$. hexagonus records mean ACDs of $\sim 450 \mathrm{~m}$ and is thus the deepest dwelling species from the analysed species of this study. It calcifies its test in oxygen-depleted, but nutrient-rich water masses. The same trend has been observed in other studies from different ocean basins. Temperature and seawater chemistry are more stable in subsurface waters compared to surface water conditions. As a consequence, G. hexagonus calcifies in $\delta^{13} \mathrm{C}$-equilibrium with ambient seawater, and hence, this species serves as an archive for tracing nutrient variations in equatorial Pacific mode and intermediate water masses being sourced in extra-topical regions.

\section{Acknowledgements}

This work was funded by the German Ministry for Education and Research (BMBF - Bundesministerium für Bildung und Forschung) in the framework of the joint project Manihiki II (03G0225B). We thank the captain, crew and participants of RV SONNE cruise SO225 for retrieving the studied material. B. Donner and M. Kucera are acknowledged for helping with foraminiferal identification. We are grateful to B. Glückselig, J. Voigt, L. Schönborn, G. Meyer and A. Mackensen for helping with sample preparation, $\mathrm{Mg} / \mathrm{Ca}$ evaluation and isotope analyses. We express our thanks to J. Roberts for language assistance. We thank the editor Frans Jorissen and two anonymous reviewers for their help in improving the quality of the manuscript. The data of this study are available at PANGEA (URL: http://www.pangaea.de).

\section{Appendix A. Species list}

Globigerinella spp. (Cushman 1927), Globigerinita glutinata (Egger 1893), Globigerinoides ruber var. white (d'Orbigny 1839), Globigerinoides sacculifer (Brady 1877), Globoquadrina conglomerata (Schwager 1866), Globorotalia hirsuta (d'Orbigny, 1839), Globorotalia menardii (d'Orbigny 1865), Globorotalia scitula (Brady, 1882), Globorotalia truncatulinoides (d'Orbigny, 1839), Globorotalia spp. (Cushman 1927), Globorotaloides hexagonus (Natland 1938), Neogloboquadrina dutertrei (d'Orbigny 1839), and Pulleniatina obliquiloculata (Parker and Jones 1862).

\section{Appendix B. Supplementary data}

Supplementary data to this article can be found online at http://dx. doi.org/10.1016/j.marmicro.2016.08.004.

\section{References}

Anand, P., Elderfield, H., Conte, M.H., 2003. Calibration of Mg/Ca thermometry in planktonic foraminifera from a sediment trap time series. Paleoceanography 18, 1050. http://dx.doi.org/10.1029/2002PA000846.

Andreasen, D.J., Ravelo, A.C., 1997. Tropical Pacific Ocean thermocline depth reconstructions for the Last Glacial Maximum. Paleoceanography 12, 395-413.

Bé, A.W.H., 1959. Ecology of recent planktonic foraminifera. Part 1. Areal distribution in the western North Atlantic. Micropaleontology 5, 77-100.

Bé, A.W.H., 1962. Quantitative multiple opening-and-closing plankton samplers. DeepSea Res. 6, 373-392

Bé, A.W.H., 1977. An ecological, zoogeographic and taxonomic review of recent planktonic foraminifera. In: Ramsay, A.T.S. (Ed.), Oceanic Micropaleontology. Academic Press, London, pp. 1-100.

Bé, A.W.H., Tolderlund, D.S., 1971. Distribution and ecology of living planktonic foraminifera in surface waters of the Atlantic and Indian Oceans. In: Funnel, B.M., Riedel, W.R. (Eds.), The Micropaleontology of Oceans. University Press, Cambridge, pp. 105-149.

Bé, A.W.H., Bishop, J.K.B., Sverdlove, M.S., Gardner, W.D., 1985. Standing stock, vertical distribution and flux of planktonic foraminifera in the Panama Basin. Mar. Micropaleontol. 9, 307-333.

Bé, A.W.H., Spero, H.J., Anderson, O.R., 1982. Effects of symbiont elimination and reinfection on the life processes of the planktonic foraminifer Globigerinoides sacculifer. Mar. Biol. 70, 73-86.

Beiersdorf, H., Bickert, T., Cepek, P., Fenner, J., Petersen, N., Schönfeld, J., Weiss, W., Won, M.Z., 1995. High-resolution stratigraphy and the response of biota to late Cenozoic environmental changes in the central equatorial Pacific Ocean (Manihiki Plateau). Mar. Geol. 125, 29-59.

Bemis, B.E., Spero, H.J., Bijma, J., Lea, D.W., 1998. Reevaluation of the oxygen isotopic composition of planktonic foraminifera: experimental results and revised paleotemperature equations. Paleoceanography 13, 150-160.

Berger, W.H., Killingley, J.S., Vincent, E., 1978. Stable isotopes in Deep-Sea carbonates: box core ERDC-92, west equatorial Pacific. Oceanol. Acta 1, 203-216.

Bijma, J., Hemleben, C., 1994. Population dynamics of the planktonic foraminifer Globigerinoides sacculifer (Brady) from the central Red Sea. Deep-Sea Res. I Oceanogr. Res. Pap. 41, 485-510.

Bijma, J., Faber, W.W., Hemleben, C., 1990. Temperature and salinity limits for growth and survival of some planktonic foraminifers in laboratory cultures. J. Foraminifer. Res. 20, 95-116. 
Bijma, J., Spero, H.J., Lea, D.W., 1999. Reassessing foraminiferal stable isotope geochemistry: impact of the oceanic carbonate system (experimental results). In: Fischer, G., Wefer G. (Eds.), Use of Proxies in Paleoceanography. Springer, Berlin, Heidelberg, pp. 489-512.

Birch, H., Coxall, H.K., Pearson, P.N., Kroon, D., O'Regan, M., 2013. Planktonic foraminifera stable isotopes and water column structure: disentangling ecological signals. Mar. Micropaleontol. 101, 127-145.

Blain, S., Leynaert, A., Tréguer, P., Chretiennot-Dinet, M.-J., Rodier, M., 1997. Biomass, growth rates and limitation of Equatorial Pacific diatoms. Deep-Sea Res. I Oceanogr. Res. Pap. 44, 1255-1275.

Blanchot, J., André, J.M., Navarette, C., Neveux, J., Radenac, M.H., 2001. Picophytoplankton in the equatorial Pacific: vertical distributions in the warm pool and in the high nutrient low chlorophyll conditions. Deep-Sea Res. I Oceanogr. Res. Pap. 48, 297-314.

Collins, M., An, S.-I., Cai, W., Ganachaud, A., Guilyardi, E., Jin, F.-F., Jochum, M., Lengaigne, M., Power, S., Timmermann, A., Vecchi, G., Wittenberg, A., 2010. The impact of global warming on the tropical Pacific Ocean and El Nino. Nat. Geosci. 3, 391-397.

Dansgaard, W., 1964. Stable isotopes in precipitation. Tellus 16, 436-468.

de Nooijer, L.J., Hathorne, E.C., Reichart, G.J., Langer, G., Bijma, J., 2014. Variability in calcitic $\mathrm{Mg} / \mathrm{Ca}$ and $\mathrm{Sr} / \mathrm{Ca}$ ratios in clones of the benthic foraminifer Ammonia tepida. Mar. Micropaleontol. 107, 32-43.

Dekens, P.S., Lea, D.W., Pak, D.K., Spero, H.J., 2002. Core top calibration of Mg/Ca in tropical foraminifera: refining paleotemperature estimation. Geochem. Geophys. Geosyst. 3, $1-29$.

Dueñas-Bohórquez, A., da Rocha, R.E., Kuroyanagi, A., Bijma, J., Reichart, G.-J., 2009. Effect of salinity and seawater calcite saturation state on $\mathrm{Mg}$ and $\mathrm{Sr}$ incorporation in cultured planktonic foraminifera. Marine Micropaleontology 73, 178-189.

Dueñas-Bohórquez, A., da Rocha, R.E., Kuroyanagi, A., de Nooijer, L.J., Bijma, J., Reichart, G.J., 2011. Interindividual variability and ontogenetic effects on $\mathrm{Mg}$ and $\mathrm{Sr}$ incorporation in the planktonic foraminifer Globigerinoides sacculifer. Geochimica et Cosmochimica Acta 75, 520-532.

Elderfield, H., Ganssen, G., 2000. Past temperature and $\delta^{18} \mathrm{O}$ of surface ocean waters inferred from foraminiferal $\mathrm{Mg} / \mathrm{Ca}$ ratios. Nature 405, 442-445.

Elderfield, H., Vautravers, M., Cooper, M., 2002. The relationship between shell size and $\mathrm{Mg} / \mathrm{Ca}, \mathrm{Sr} / \mathrm{Ca}, \delta^{18} \mathrm{O}$, and $\delta^{13} \mathrm{C}$ of species of planktonic foraminifera. Geochem. Geophys. Geosyst. 3, 1-13.

Emiliani, C., 1955. Pleistocene temperatures. J. Geol. 63, 538-578.

Erez, J., Luz, B., 1983. Experimental paleotemperature equation for planktonic foraminifera. Geochim. Cosmochim. Acta 47, 1025-1031.

Fairbanks, R.G., Sverdlove, M., Free, R., Wiebe, P.H., Be, A.W.H., 1982. Vertical distribution and isotopic fractionation of living planktonic foraminifera from the Panama Basin. Nature 298, 841-844

Faul, K.L., Ravelo, A.C., Delaney, M.L., 2000. Reconstructions of upwelling, productivity, and photic zone depth in the eastern equatorial Pacific Ocean using planktonic foraminiferal stable isotopes and abundances. J. Foraminifer. Res. 30, 110-125.

Fine, R.A., Lukas, R., Bingham, F.M., Warner, M.J., Gammon, R.H., 1994. The western equatorial Pacific: a water mass crossroads. J. Geophys. Res. Oceans 99, 25063-25080.

Firing, E., Wijffels, S.E., Hacker, P., 1998. Equatorial subthermocline currents across the Pacific. J. Geophys. Res. Oceans 103, 21413-21423.

Friedrich, O., Schiebel, R., Wilson, P.A., Weldeab, S., Beer, C.J., Cooper, M.J., Fiebig, J., 2012. Influence of test size, water depth, and ecology on $\mathrm{Mg} / \mathrm{Ca}, \mathrm{Sr} / \mathrm{Ca}, \delta^{18} \mathrm{O}$ and $\delta^{13} \mathrm{C}$ in nine modern species of planktonic foraminifers. Earth Planet. Sci. Lett. 319-320, 133-145.

Goodman, P.J., Hazeleger, W., de Vries, P., Cane, M., 2005. Pathways into the Pacific equatorial undercurrent: a trajectory analysis. J. Phys. Oceanogr. 35, 2134-2151.

Grenier, M., Cravatte, S., Blanke, B., Menkes, C., Koch-Larrouy, A., Durand, F., Melet, A., Jeandel, C., 2011. From the western boundary currents to the Pacific equatorial undercurrent: modeled pathways and water mass evolutions. J. Geophys. Res. Oceans 116, C12044.

Hamilton, C.P., Spero, H.J., Bijma, J., Lea, D.W., 2008. Geochemical investigation of gametogenic calcite addition in the planktonic foraminifera Orbulina universa. Marine Micropaleontology 68, 256-267.

Hathorne, E.C., Gagnon, A., Felis, T., Adkins, J., Asami, R., Boer, W., Caillon, N., Case, D., Cobb, K.M., Douville, E., de Menocal, P., Eisenhauer, A., Garbe-Schönberg, D. Geibert, W., Goldstein, S., Hughen, K., Inoue, M., Kawahata, H., Kölling, M., Cornec, F.L., Linsley, B.K., McGregor, H.V., Montagna, P., Nurhati, I.S., Quinn, T.M., Raddatz, J., Rebaubier, H., Robinson, L., Sadekov, A., Sherrell, R., Sinclair, D., Tudhope, A.W., Wei, G., Wong, H., Wu, H.C., You, C.-F., 2013. Interlaboratory study for coral $\mathrm{Sr} / \mathrm{Ca}$ and other element/Ca ratio measurements. Geochem. Geophys. Geosyst. 14, 3730-3750.

Hemleben, C., Bijma, J., 1994. Foraminiferal population dynamics and stable carbon isotopes. In: Zahn, R., Pedersen, T.F., Kaminski, M., Labeyrie, L. (Eds.), Carbon Cycling in the Glacial Ocean: Constraints on the Ocean's Role in Global Change. Elsevier, Fellhorst, pp. 145-166.

Hemleben, C., Spindler, M., Anderson, O.R., 1989. Modern Planktonic Foraminifera. Springer, New York.

Hillbrecht, H., 1996. Extant Planktonic Foraminifera and the Physical Environment in the Atlantic and Indian Oceans Mitteilungen aus dem Geologischen Institut der Eidgen Technischen Hochschule und der Universität Zürichhttp://www.ngdc.noaa.gov/ mgg/geology/hh1996/aa_start.html.

Hut, G., 1987. Consultants Group Meeting on Stable Isotope Reference Samples for Geochemical and Hydrological Inves. International Atomic Energy Agency, Vienna.

Itou, M., Ono, T., Oba, T., Noriki, S., 2001. Isotopic composition and morphology of living Globorotalia scitula: a new proxy of sub-intermediate ocean carbonate chemistry? Mar. Micropaleontol. 42, 189-210.

Jochum, K.P., Weis, U., Stoll, B., Kuzmin, D., Yang, Q., Raczek, I., Jacob, D.E., Stracke, A., Birbaum, K., Frick, D.A., Günther, D., Enzweiler, J., 2011. Determination of reference values for NIST SRM 610-617 glasses following ISO guidelines. Geostand. Geoanal. Res. 35, 397-429.

Johnson, G.C., Moore, D.W., 1997. The Pacific subsurface countercurrents and an inertial model. J. Phys. Oceanogr. 27, 2448-2459.
Kawahata, H., Nishimura, A., Gagan, M.K., 2002. Seasonal change in foraminiferal production in the western equatorial Pacific warm pool: evidence from sediment trap experiments. Deep-Sea Res. II Top. Stud. Oceanogr. 49, 2783-2800.

Kemle-von Mücke, S., Oberhänsli, H., 1999. The distribution of living planktic foraminifera in relation to southeast Atlantic oceanography. In: Fischer, G., Wefer, G. (Eds.), Use of Proxies in Paleoceanography: Examples from the South Atlantic. Springer, Berlin, Heidelberg, pp. 91-115.

Key, R.M., Kozyr, A., Sabine, C.L., Lee, K., Wanninkhof, R., Bullister, J.L., Feely, R.A., Millero, F.J., Mordy, C., Peng, T.-H., 2004. A global ocean carbon climatology: results from Global Data Analysis Project (GLODAP). Glob. Biogeochem. Cycles 18, GB4031.

Kiefer, T., McCave, I.N., Elderfield, H., 2006. Antarctic control on tropical Indian Ocean sea surface temperature and hydrography. Geophys. Res. Lett. 33, L24612.

Kim, S.-T., O'Neil, J.R., 1997. Equilibrium and nonequilibrium oxygen isotope effects in synthetic carbonates. Geochim. Cosmochim. Acta 61, 3461-3475.

King, A.L., Howard, W.R., 2003. Planktonic foraminiferal flux seasonality in Subantarctic sediment traps: a test for paleoclimate reconstructions. Paleoceanography 18 (1), 1019

King, A.L., Howard, W.R., 2005. $\delta^{18}$ O seasonality of planktonic foraminifera from Southern Ocean sediment traps: latitudinal gradients and implications for paleoclimate reconstructions. Mar. Micropaleontol. 56, 1-24.

Kroon, D., Darling, K., 1995. Size and upwelling control of the stable isotope composition of Neogloboquadrina dutertrei (d'Orbigny), Globigerinoides ruber (d'Orbigny) and Globingerina bulloides (d'Orbigny): examples from the Panama Basin and Arabian Sea. J. Foraminifer. Res. 25, 39-52.

Kunioka, D., Shirai, K., Takahata, N., Sano, Y., Toyofuku, T., Ujiie, Y., 2006. Microdistribution of $\mathrm{Mg} / \mathrm{Ca}, \mathrm{Sr} / \mathrm{Ca}$, and $\mathrm{Ba} / \mathrm{Ca}$ ratios in Pulleniatina obliquiloculata test by using a NanoSIMS: implication for the vital effect mechanism. Geochem. Geophys. Geosyst. 7, 1525-2027.

Kuroyanagi, A., Tsuchiya, M., Kawahata, H., Kitazato, H., 2008. The occurrence of two genotypes of the planktonic foraminifer Globigerinoides ruber (white) and paleo-environmental implications. Mar. Micropaleontol. 68, 236-243.

Le Borgne, R., Barber, R.T., Delcroix, T., Inoue, H.Y., Mackey, D.J., Rodier, M., 2002. Pacific warm pool and divergence: temporal and zonal variations on the equator and their effects on the biological pump. Deep-Sea Res. II Top. Stud. Oceanogr. 49, 2471-2512.

Lea, D.W., Mashiotta, T.A., Spero, H.J., 1999. Controls on magnesium and strontium uptake in planktonic foraminifera determined by live culturing. Geochim. Cosmochim. Acta 63, 2369-2379.

Lea, D.W., Pak, D.K., Spero, H.J., 2000. Climate impact of Late Quaternary equatorial Pacific Sea surface temperature variations. Science 289, 1719-1724.

Leduc, G., Vidal, L., Cartapanis, O., Bard, E., 2009. Modes of eastern equatorial Pacific thermocline variability: implications for ENSO dynamics over the last glacial period. Paleoceanography 24, PA3202.

Lin, H.-L., Wang, W.-C., Hung, G.-W., 2004. Seasonal variation of planktonic foraminiferal isotopic composition from sediment traps in the South China Sea. Mar Micropaleontol. 53, 447-460.

Locarnini, R.A., Mishonov, A.V., Antonov, J.I., Boyer, T.P., Garcia, H.E., Baranova, O.K. Zweng, M.M., Paver, C.R., Reagan, J.R., Johnson, D.R., Hamilton, M., Seidov, D., 2013. In: Levitus, S., Mishonov, A. (Eds.), World Ocean Atlas 2013, Volume 1: Temperature. NOAA Atlas NESDIS 73, MD 40 pp.

Loubere, P., 2001. Nutrient and oceanographic changes in the Eastern Equatorial Pacific from the last full Glacial to the Present. Glob. Planet. Chang. 29, 77-98.

Lynch-Stieglitz, J., Polissar, P.J., Jacobel, A.W., Hovan, S.A., Pockalny, R.A., Lyle, M., Murray R.W., Ravelo, A.C., Bova, S.C., Dunlea, A.G., Ford, H.L., Hertzberg, J.E., Wertman, C.A., Maloney, A.E., Shackford, J.K., Wejnert, K., Xie, R.C., 2015. Glacial-interglacial changes in central tropical Pacific surface seawater property gradients. Paleoceanography 30 423-438.

Marchant, M., Hebbeln, D., Wefer, G., 1998. Seasonal flux patterns of planktonic foraminifera in the Peru-Chile current. Deep-Sea Res. I Oceanogr. Res. Pap. 45, 1161-1185.

McGregor, S., Timmermann, A., Stuecker, M.F., England, M.H., Merrifield, M., Jin, F.-F., Chikamoto, Y., 2014. Recent Walker circulation strengthening and Pacific cooling amplified by Atlantic warming. Nat. Clim. Chang. 4, 888-892.

Mewes, A., Langer, G., Thoms, S., Nehrke, G., Reichart, G.J., de Nooijer, L.J., Bijma, J., 2015. Impact of seawater $\left[\mathrm{Ca}^{2+}\right]$ on the calcification and calciteMg/Ca of Amphistegina lessonii. Biogeosciences 12, 2153-2162.

Mohtadi, M., Steinke, S., Groeneveld, J., Fink, H.G., Rixen, T., Hebbeln, D., Donner, B. Herunadi, B., 2009. Low-latitude control on seasonal and interannual changes in planktonic foraminiferal flux and shell geochemistry off south Java: a sediment trap study. Paleoceanography 24, PA1201.

Morey, A.E., Mix, A.C., Pisias, N.G., 2005. Planktonic foraminiferal assemblages preserved in surface sediments correspond to multiple environment variables. Quat. Sci. Rev. 24, 925-950.

Mulitza, S., Donner, B., Fischer, G., Paul, A., Pätzold, J., Rühlemann, C., Segl, M., 2004. The South Atlantic oxygen isotope record of planktonic foraminifera. In: Wefer, G., Mulitza, S., Ratmeyer, V. (Eds.), The South Atlantic in the Late Quaternary: Reconstruction of Material Budgets and Current Systems. Springer, Berlin, pp. 121-142.

Mulitza, S., Wolff, T., Pätzold, J., Hale, W., Wefer, G., 1998. Temperature sensitivity of planktonic foraminifera and its influence on the oxygen isotope record. Mar. Micropaleontol. 33, 223-240.

NASA Ocean Biology, 2015. Sea-viewing Wide Field-of-view Sensor (SeaWiFS) Ocean Color Data, 2014.0 Reprocessing. NASA OB.DAAC, Greenbelt, MD, USA http://dx.doi. org/10.5067/ORBVIEW-2/SEAWIFS_OC.2014.0 (Accessed 2015/02/08).

Nehrke, G., Keul, N., Langer, G., de Nooijer, L.J., Bijma, J., Meibom, A., 2013. A new model for biomineralization and trace-element signatures of Foraminifera tests. Biogeosciences 10, 6759-6767.

Ni, Y., Foster, G.L., Bailey, T., Elliott, T., Schmidt, D.N., Pearson, P., Haley, B., Coath, C., 2007. A core top assessment of proxies for the ocean carbonate system in surface-dwelling foraminifers. Paleoceanography 22, PA3212. 
Niebler, H.S., Hubberten, H.W., Gersonde, R., 1999. Oxygen isotope values of planktonic foraminifera: A tool for the reconstruction of surface water stratification. In: Fischer, G., Wefer, G. (Eds.), Use of Proxies in Paleoceanography. Springer, Berlin, Heidelberg, pp. 165-189.

NOAA, 2015a. Oceanic Niño Index. http://www.cpc.ncep.noaa.gov/products/analysis_ monitoring/ensostuff/ensoyears.shtml.

NOAA, 2015b. Equatorial Pacific zonal wind field. https://www.ncdc.noaa.gov/ teleconnections/enso/indicators/uwind.php.

Nürnberg, D., 1995. Magnesium in tests of Neogloboquadrina pachyderma sinistral from high northern and southern latitudes. J. Foraminifer. Res. 25, 350-368.

Nürnberg, D., Bijma, J., Hemleben, C., 1996. Assessing the reliability of magnesium in foraminiferal calcite as a proxy for water mass temperatures. Geochim. Cosmochim. Acta 60, 803-814.

Nürnberg, D., Böschen, T., Doering, K., Mollier-Vogel, E., Raddatz, J., Schneider, R., 2015. Sea surface and subsurface circulation dynamics off equatorial Peru during the last $\sim 17$ kyr. Paleoceanography, PA002706.

Oppo, D.W., Fairbanks, R.G., 1989. Carbon isotope composition of tropical surface water during the past 22,000 years. Paleoceanography 4, 333-351.

Ortiz, J.D., Mix, A.C., Rugh, W., Watkins, J.M., Collier, R.W., 1996. Deep-dwelling planktonic foraminifera of the northeastern Pacific Ocean reveal environmental control of oxygen and carbon isotopic disequilibria. Geochim. Cosmochim. Acta 60, 4509-4523.

Parker, F.L., 1962. Planktonic foraminiferal species in Pacific sediments. Micropaleontology $8,219-254$.

Pena, L.D., Cacho, I., Ferretti, P., Hall, M.A., 2008. El Niño-Southern Oscillation-like variability during glacial terminations and interlatitudinal teleconnections. Paleoceanography 23, PA3101.

Rafter, P.A., Sigman, D.M., 2015. Spatial distribution and temporal variation of nitrate nitrogen and oxygen isotopes in the upper equatorial Pacific Ocean. Limnol. Oceanogr. 61, 14-31.

Ravelo, A.C., Fairbanks, R.G., 1992. Oxygen isotopic composition of multiple species of planktonic foraminifera: Recorders of the modern photic zone temperature gradient Paleoceanography 7, 815-831.

Ravelo, A.C., Fairbanks, R.G., Philander, S.G.H., 1990. Reconstructing tropical Atlantic hydrography using planktontic foraminifera and an ocean model. Paleoceanography 5 , 409-431.

Regenberg, M., Steph, S., Nürnberg, D., Tiedemann, R., Garbe-Schönberg, D., 2009. Calibrating $\mathrm{Mg} / \mathrm{Ca}$ ratios of multiple planktonic foraminiferal species with $\delta^{18} \mathrm{O}$-calcification temperatures: paleothermometry for the upper water column. Earth Planet. Sci. Lett. 278, 324-336.

Reverdin, G., Morliere, A., Gerard, E., 1991. Compagne Oceanographique Trans-Pacifique (janvier-mars 1991) Receuil de données. Rapport interne LODYC 91/13 University of Paris $341 \mathrm{pp}$.

Rincón-Martínez, D., Steph, S., Lamy, F., Mix, A., Tiedemann, R., 2011. Tracking the equatorial front in the eastern equatorial Pacific Ocean by the isotopic and faunal composition of planktonic foraminifera. Mar. Micropaleontol. 79, 24-40.

Rippert, N., Baumann, K.-H., Pätzold, J., 2015. Thermocline fluctuations in the western tropical Indian Ocean during the past 35 ka. J. Quat. Sci. 30, 201-210.

Rowe, G.D., Firing, E., Johnson, G.C., 2000. Pacific equatorial subsurface countercurrent velocity, transport, and potential vorticity. J. Phys. Oceanogr. 30, 1172-1187.

Russon, T., Elliot, M., Sadekov, A., Cabioch, G., Corrège, T., De Deckker, P., 2010. Inter-hemispheric asymmetry in the early Pleistocene Pacific warm pool. Geophys. Res. Lett. 37, L11601.

Sadekov, A.Y., Ganeshram, R., Pichevin, L., Berdin, R., McClymont, E., Elderfield, H., Tudhope, A.W., 2013. Palaeoclimate reconstructions reveal a strong link between $\mathrm{E}$ Nino-Southern Oscillation and Tropical Pacific mean state. Nat. Commun. 4, 2692.

Sagawa, T., Yokoyama, Y., Ikehara, M., Kuwae, M., 2012. Shoaling of the western equatoria Pacific thermocline during the last glacial maximum inferred from multispecies temperature reconstruction of planktonic foraminifera. Palaeogeogr. Palaeoclimatol. Palaeoecol. 346-347, 120-129.

Sarmiento, J.L., Gruber, N., Brzezinski, M.A., Dunne, J.P., 2004. High-latitude controls of thermocline nutrients and low latitude biological productivity. Nature 427, 56-60.

Schiebel, R., Hemleben, C., 2005. Modern planktonic foraminifera, Paläontologische Zeitschrift. Schweizerbart'sche Verlagsbuchhandlung, Stuttgart, pp. 135-148.

Schiebel, R., Waniek, J., Bork, M., Hemleben, C., 2001. Planktonic foraminiferal production stimulated by chlorophyll redistribution and entrainment of nutrients. Deep-Sea Res. I Oceanogr. Res. Pap. 48, 721-740.

Schlitzer, R., 2012. Ocean Data View. http://odv.awi.de.

Schmidt, G.A., Bigg, G.R., Rohling, E.J., 1999. Global Seawater Oxygen-18 Database-v1.21. http://data.giss.nasa.gov/o18data/.

Schmuker, B., Schiebel, R., 2002. Planktonic foraminifers and hydrography of the eastern and northern Caribbean Sea. Mar. Micropaleontol. 46, 387-403.

Shackleton, N.J., 1974. Attainment of isotopic equilibrium between ocean water and the benthic foraminifera genua Uvigerina: isotopic changes in the ocean during the last glacial. Centre Natl. Rech. Sci. Coll. Inter. 219, 203-209.

Spero, H.J., Lea, D.W., 1993. Intraspecific stable isotope variability in the planktonic foraminifera Globigerinoides sacculifer: results from laboratory experiments. Mar. Micropaleontol. 22, 221-234
Spero, H.J., Parker, S.L., 1985. Photosynthesis in the symbiotic planktonic foraminifer Orbulina universa, and its potential contribution to oceanic primary productivity. J. Foraminifer. Res. 15, 273-281.

Spero, H.J., Bijma, J., Lea, D.W., Bemis, B.E., 1997. Effect of seawater carbonate concentration on foraminiferal carbon and oxygen isotopes. Nature 390, 497-500

Spero, H.J., Eggins, S.M., Russell, A.D., Vetter, L., Kilburn, M.R., Hönisch, B., 2015. Timing and mechanism for intratest $\mathrm{Mg} / \mathrm{Ca}$ variability in a living planktic foraminifer. Earth Planet. Sci. Lett. 409, 32-42.

Spero, H.J., Lerche, I., Williams, D.F., 1991. Opening the carbon isotope "vital effect" black box, 2, quantitative model for interpreting foraminiferal carbon isotope data. Paleoceanography 6, 639-655.

Spero, H.J., Mielke, K.M., Kalve, E.M., Lea, D.W., Pak, D.K., 2003. Multispecies approach to reconstructing eastern equatorial Pacific thermocline hydrography during the past 360 kyr. Paleoceanography 18, 1022

Steinke, S., Chiu, H.-Y., Yu, P.-S., Shen, C.-C., Löwemark, L., Mii, H.-S., Chen, M.-T., 2005. Mg/ Ca ratios of two Globigerinoides ruber (white) morphotypes: implications for reconstructing past tropical/subtropical surface water conditions. Geochem. Geophys. Geosyst. 6, Q11005.

Steph, S., Regenberg, M., Tiedemann, R., Mulitza, S., Nürnberg, D., 2009. Stable isotopes of planktonic foraminifera from tropical Atlantic/Caribbean core-tops: implications for reconstructing upper ocean stratification. Mar. Micropaleontol. 71, 1-19.

Stott, L., Poulsen, C., Lund, S., Thunell, R., 2002. Super ENSO and global climate oscillations at millennial time scales. Science 297, 222-226.

Thunell, R.C., Honjo, S., 1981. Planktonic foraminiferal flux to the deep ocean: Sediment trap results from the tropical Atlantic and the central Pacific. Mar. Geol. 40, 237-253.

Thunell, R.C., Curry, W.B., Honjo, S., 1983. Seasonal variation in the flux of planktonic foraminifera: time series sediment trap results from the Panama Basin. Earth Planet. Sci. Lett. 64, 44-55.

Tomczak, M., Godfrey, J.S., 1994. Regional Oceanography: An Introduction. Pergamon, Oxford $422 \mathrm{~S}$

Tsuchiya, M., 1972. A subsurface north equatorial countercurrent in the eastern Pacific Ocean. J. Geophys. Res. 77, 5981-5986.

Wang, L., 2000. Isotopic signals in two morphotypes of Globigerinoides ruber (white) from the South China Sea: implications for monsoon climate change during the last glacial cycle. Palaeogeogr. Palaeoclimatol. Palaeoecol. 161, 381-394.

Wara, M.W., Ravelo, A.C., Delaney, M.L., 2005. Permanent El Niño-Like conditions during the Pliocene warm period. Science 309, 758-761.

Watkins, J.M., Mix, A.C., Wilson, J., 1996. Living planktonic foraminifera: tracers of circulation and productivity regimes in the central equatorial Pacific. Deep-Sea Res. II Top. Stud. Oceanogr. 43, 1257-1282.

Watkins, J.M., Mix, A.C., Wilson, J., 1998. Living planktonic foraminifera in the central tropical Pacific Ocean: articulating the equatorial 'cold tongue' during La Niña, 1992. Mar. Micropaleontol. 33, 157-174.

Wefer, G., Berger, W.H., 1991. Isotope paleontology: growth and composition of extant calcareous species. Mar. Geol. 100, 207-248.

Wejnert, K.E., Thunell, R.C., Astor, Y., 2013. Comparison of species-specific oxygen isotope paleotemperature equations: sensitivity analysis using planktonic foraminifera from the Cariaco Basin, Venezuela. Mar. Micropaleontol. 101, 76-88.

Werner, R., Nürnberg, D., Hauff, F., Party, S.S.S., 2013. RV SONNE Fahrtbericht/Cruise Report SO225, Manihiki II Leg 2, the Manihiki Plateau - Origin, Structure and Effects of Oceanic Plateaus and Pleistocene Dynamic of the West Pacific Warm Water Pool: 19.11.2012-06.01.2013, Suva/Fiji - Auckland/New Zealand, GEOMAR Report. GEOMAR Helmholtz-Zentrum für Ozeanforschung, Kiel, Germany (176 pp.).

Wilke, I., Meggers, H., Bickert, T., 2009. Depth habitats and seasonal distributions of recent planktonic foraminifers in the Canary Islands region $\left(29^{\circ} \mathrm{N}\right)$ based on oxygen isotopes. Deep-Sea Res. I Oceanogr. Res. Pap. 56, 89-106.

Wyrtki, K., Kilonsky, B., 1984. Mean water and current structure during the Hawaii-to-Tahiti shuttle experiment. J. Phys. Oceanogr. 14, 242-254

Yamanaka, Y., Tajika, E., 1996. The role of the vertical fluxes of particulate organic matter and calcite in the oceanic carbon cycle: studies using an ocean biogeochemical general circulation model. Glob. Biogeochem. Cycles 10, 361-382.

Yamasaki, M., Sasaki, A., Oda, M., Domitsu, H., 2008. Western equatorial Pacific planktonic foraminiferal fluxes and assemblages during a La Niña year (1999. Mar. Micropaleontol. 66, 304-319.

Yan, X.H., Ho, C.R., Zheng, Q., Klemas, V., 1992. Temperature and size variabilities of the western Pacific warm pool. Science 258, 1643-1645.

Žarić, S., Donner, B., Fischer, G., Mulitza, S., Wefer, G., 2005. Sensitivity of planktonic foraminifera to sea surface temperature and export production as derived from sediment trap data. Mar. Micropaleontol. 55, 75-105.

Zweng, M.M., Reagan, J.R., Antonov, J.I., Locarnini, R.A., Mishonov, A.V., Boyer, T.P., Garcia, H.E., Baranova, O.K., Johnson, D.R., Seidov, D., Biddle, M.M., 2013. In: Levitus, S, Mishonov, A. (Eds.), World Ocean Atlas 2013, Volume 2: Salinity. NOAA Atlas NESDIS, MD (39 pp.) 